\title{
22. PALYNOLOGY OF SITES 603 AND 605, LEG 93, DEEP SEA DRILLING PROJECT ${ }^{1}$
}

\author{
Daniel Habib, Queens College and Graduate School of the City University of New York \\ and \\ Warren S. Drugg, Chevron Oil Field Research Company ${ }^{2}$
}

\begin{abstract}
The palynology of two sections recovered during Leg 93 drilling by the Deep Sea Drilling Project in the continental rise along the western margin of the North Atlantic is reported. In Hole 603B at Site 603, the dinoflagellate stratigraphy indicates that the interval from Cores 603B-82 to 603B-26 ranges in age from late Berriasian to Santonian. The BlakeBahama Formation ranges from late Berriasian to Aptian. The Hatteras Formation ranges from Aptian to Cenomanian, although the uppermost part may be Turonian. Dinoflagellate evidence from the middle part of the Plantagenet Formation indicates an age from late Coniacian or early Santonian to Santonian within the interval of Cores 603B-28 to 603B-26. Magnetic polarity evidence of the stratigraphy of the Early Cretaceous for the western North Atlantic indicates a reliable correlation with the dinoflagellate zonation.

The stratigraphic sequence of palynologically defined organic facies in carbonaceous claystone lithologies in Hole 603B shows that organic stratigraphic units consisting predominantly of fecal-pellet-derived, pelagic organic matter (xenomorphic facies) alternate with units consisting predominantly of terrigenous organic matter (tracheal and exinitic facies), corresponding to that described from other sites in the North Atlantic. A terrigenous organic facies is identified for the first time from the Plantagenet Formation. The claystone organic facies and major lithofacies are closely correlated. The tracheal and exinitic facies occur in carbonaceous terrigenous claystones and claystone turbidites associated with sandstone/siltstone terrigenous turbidites. The xenomorphic facies occurs in claystones within pelagic limestones lacking any turbidites, and in blackish, noncalcareous claystones which correlate in age with the marine-carbon-rich sapropels which are widespread in the North Atlantic Cenomanian. This facies also occurs with an admixture of terrigenous organic particles in the Blake-Bahama Formation, but the mixture is consistent with the submarine fan setting of this interval. The concentration of refractory organic matter (carbonized particles) in the micrinitic and carbonized tracheal facies is considered to be the result, at least in part, of the oxidation of sediment buried below a surface slowly accumulating pelagic clays below the carbonate compensation depth. The progressive increase in number of dinoflagellate species per stage through the Early Cretaceous (except for the late Barremian-Aptian) may have resulted indirectly from the generally progressive rise in global sea level during this time.

At Site 605 , the dinoflagellate stratigraphy across the Cretaceous/Tertiary boundary is remarkably close to that published from the Maestrichtian and Danian of Denmark. The Maestrichtian/Danian boundary is placed precisely within Section 605-66-1 by dinoflagellate evidence, agreeing with that predicted by other microfossils.

The new dinoflagellate-cyst-based genus, Pierceites and its new species $P$. schizocystis, and the new combination $P$. (=Trithyrodinium) pentagonum (May) are proposed. Diacanthum hollisteri Habib, type species of Diacanthum, is

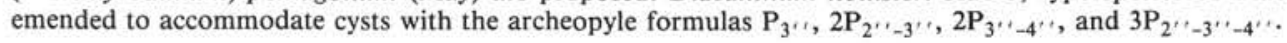

\section{INTRODUCTION}

Leg 93 of the Deep Sea Drilling Project drilled six holes at three sites along the continental margin of the eastern United States. The palynology of two sections, recovered from Site 603 (Hole 603B) and Site 605, was undertaken with the objectives of (1) dating the Cretaceous sequence at Site 603, based on its dinoflagellate stratigraphy; (2) interpreting the sedimentary history of the particulate organic matter in carbonaceous clays at Site 603 and correlating its distribution with the distribution of the major lithofacies; and (3) determining the dinoflagellate stratigraphy across the Cretaceous/Tertiary boundary at Site 605. Hole 603B was drilled in the lower continental rise at $35^{\circ} 29.71^{\prime} \mathrm{N}$ and $70^{\circ} 01.71^{\prime} \mathrm{W}$, approximately $434 \mathrm{~km}$ east of Cape Hatteras, North Carolina, in a water depth of $4633 \mathrm{~m}$. Site 605 was drilled in

\footnotetext{
${ }^{1}$ van Hinte, J. E., Wise, S. W., Jr., et al., Init. Repts. DSDP, 93: Washington (U.S. Govt, Printing Office)

2 Addresses: (Habib) Queens College and Graduate School of the City University of New York, 33 W 42 St., New York NY 10036-8099; (Drugg) Chevron Oil Field Research Co., P.O. Box 446, La Habra, CA 90631.
}

the upper continental rise in a water depth of $2194 \mathrm{~m}$ at $38^{\circ} 44.53^{\prime} \mathrm{N}$ and $72^{\circ} 36.55^{\prime} \mathrm{W}$. Figure 1 illustrates the geographic locations of these and other sites in the western North Atlantic discussed in this report.

Appendix A lists the 102 samples from Site 603 and the 8 samples from Site 605 that were investigated. At least 1 sample from each of the 61 cores at Site 603 and from each of the 6 cores at Site 605 was investigated. In certain intervals, additional core sections were sampled in the attempt to more precisely identify biostratigraphic datums. Only the core-catcher sample from Core 603B72 was studied, as this appeared to be the only part of that core that was in place. In the Hole 603B section, almost all of the samples are dark gray, greenish gray, or blackish claystones collected from core sections where the predominant lithologies are nannofossil-rich limestone and chalk, blackish noncalcareous claystones, reddish brown to greenish gray noncalcareous claystones, or quartz/mica siltstones and sandstones. Seven of the 102 samples studied are not blackish, but vary from reddish brown to dark reddish brown in color. These are 603B-22-5, 4-6 cm, 603B-24-2, 45-47 cm, 603B-30-5, 3$5 \mathrm{~cm}, 603 \mathrm{~B}-31-5,5-7 \mathrm{~cm}, 603 \mathrm{~B}-40-6,27-29 \mathrm{~cm}, 603 \mathrm{~B}-$ 


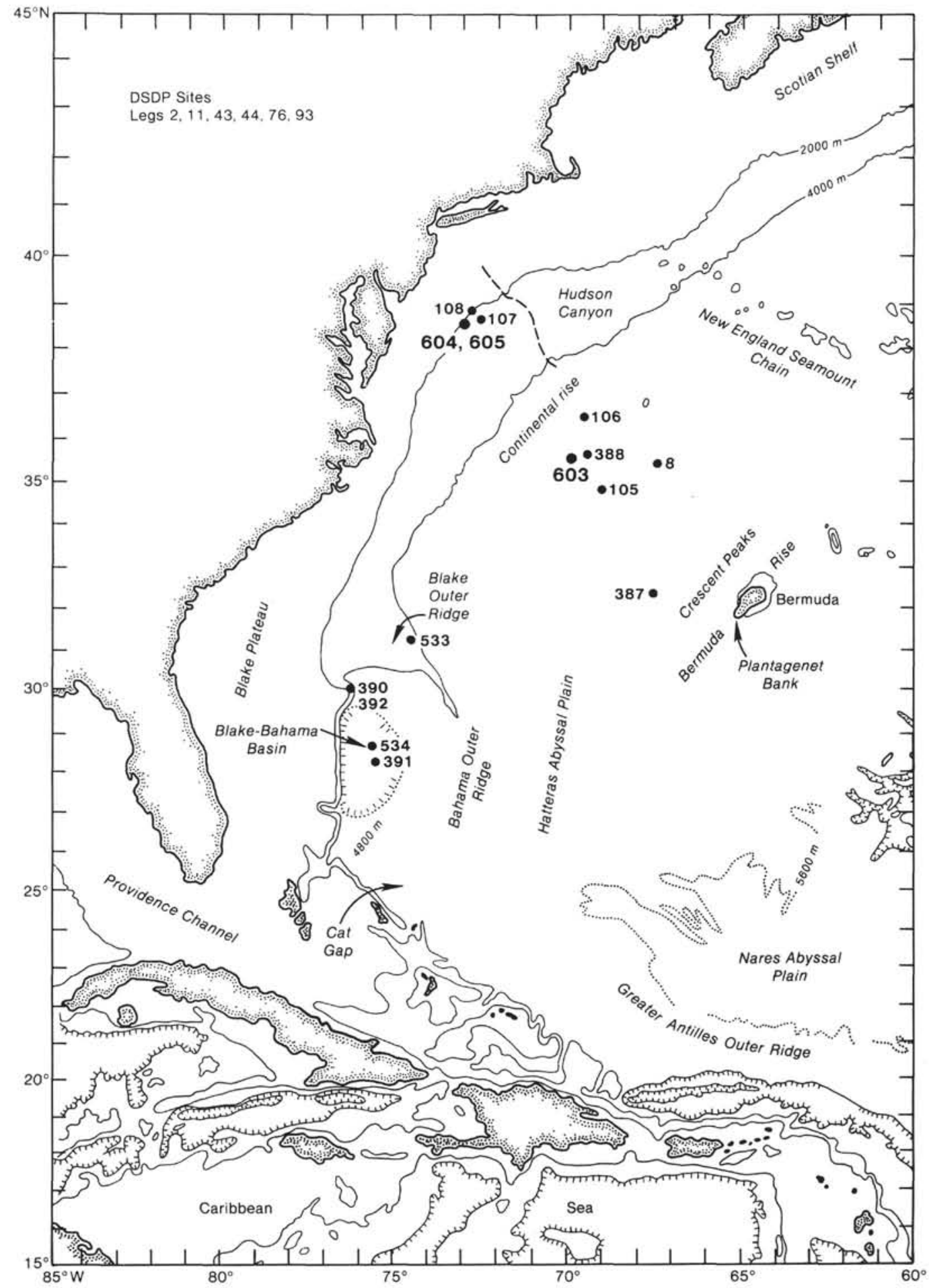

Figure 1. Location of Deep Sea Drilling Project Holes 603B and 605 in the western North Atlantic, and other sites referred to in the text.

$41-4,56-58 \mathrm{~cm}$, and $603 \mathrm{~B}-43-2,22-24 \mathrm{~cm}$. All of the samples yielded at least some organic residue after treatment with hydrochloric and hydrofluoric acids. However, 17 samples proved to be barren of palynomorphs (Appendix A), including the 7 listed above. Regardless of color, all of the barren samples were collected from "background" reddish to greenish noncalcareous pelagic claystone intervals (Site 603 chapter, this volume). All eight of the samples from Site 605 proved to be highly fossiliferous.

\section{SITE 603}

\section{Lithostratigraphy}

Drilling at Site 603 (Hole 603B) penetrated to a depth below seafloor of approximately $1576 \mathrm{~m}$. The palyno- 
logically dated interval is approximately $520 \mathrm{~m}$ thick and extends from the stratigraphic level of Core 603B-26 to the bottom of the recovered section in Core 603B-82. Based on dinoflagellate evidence, the age of this interval ranges from Santonian to late Berriasian. The lithostratigraphy is summarized and abstracted from the comprehensive description given in the Site 603 chapter, this volume, and is integrated with the principal results of the palynology presented in this paper. Three major lithostratigraphic units were distinguished; they could be correlated with the formations defined by Jansa et al. (1979) for the western North Atlantic basin. A major discovery was the coring of a thick, deep-sea fan sand turbidite facies of Early Cretaceous age (Site 603, chapter, this volume). In ascending stratigraphic sequence, the three formations are the Blake-Bahama Formation (lithologic Unit V of the site chapter), the Hatteras Formation (Unit IV) and the Plantagenet Formation (Unit III).

\section{Blake-Bahama Formation}

This formation was originally defined for calcareousnannofossil-rich limestones, marls, and chalks with terrigenous and carbonate-clast turbidites (Jansa et al., 1979). At Site 603 it is $361 \mathrm{~m}$ thick and is differentiated by the preponderance of quartz-mica siltstone and sandstone turbidites. Two subunits were distinguished by the presence or absence of turbidites.

The lower, thinner Subunit VB, in the interval from $603 \mathrm{~B}-82$ to $603 \mathrm{~B}-76-1,120 \mathrm{~cm}$, consists of alternating laminated and bioturbated nannofossil chalks and limestones lacking any turbidites. Palynological study of this subunit indicates that it ranges in age from late Berriasian to Valanginian, and that the carbonaceous layers consist predominantly of pelagic, amorphous, organic debris, dinoflagellate specimens (dinocysts), and "windblown" pollen grains. The overlying Subunit VA is approximately $298 \mathrm{~m}$ thick and consists of siltstone and sandstone turbidites, which compose $\sim 47 \%$ of this part of the section. Interbedded are blackish organic-matterrich terrigenous claystone turbidites and intervals of the nannofossil lithologies which characterize subunit VB. The organic-matter turbidites compose $\sim 25 \%$ of this subunit. According to the Site 603 chapter (this volume), the siltstone-sandstone turbidites are genetically related to the carbonaceous claystone turbidites, because there are intermediate types, and intervals occur in which there is a complete, graded sequence from sandstone to claystone. Also, the siltstone-sandstone turbiditic intervals appear to coincide with the major progradations of terrestrial deltas on the shelves of the continents bordering the Cretaceous North Atlantic (Site 603, chapter, this volume).

Subunit VA, from 603B-76-1, $120 \mathrm{~cm}$ to 603B-44-1, $32 \mathrm{~cm}$, ranges in age from Valanginian to Aptian. The organic matter is largely terrigenous, reaching a peak in Core 603B-56, of early Barremian age. Intervals characterized by poorly preserved amorphous debris also occur, but these also contain admixtures of terrigenous organic particles.

\section{Hatteras Formation}

The Hatteras Formation (Unit IV) extends from 603B$44-1,32 \mathrm{~cm}$, to $603 \mathrm{~B}-33-1,60 \mathrm{~cm}$. In the western North Atlantic, it consists of black to dark greenish gray, noncalcareous, carbonaceous claystones (Jansa et al., 1979). At several sites, the boundary with the underlying BlakeBahama Formation is marked by transitional, interbedded carbonaceous/calcareous claystones (Lancelot et al., 1972) or by reddish clay (Sheridan, Gradstein, et al., 1983; Habib, 1983). At Site 603, Unit IV is approximately $96 \mathrm{~m}$ thick. It consists of four subunits, based on the relative abundance of carbonaceous claystones. Subunit IVD consists of Aptian pelagic, greenish gray to reddish brown claystones, with only minor amounts of carbonaceous claystones, in the interval from 603B-44-1, $32 \mathrm{~cm}$, through 603B-43-1. Subunit IVC, composed of black to greenish gray claystones lacking any reddish color, extends from 603B-42,CC to 603B-41-5 and is considered to be of early Albian age. Subunit IVB represents a return to predominantly greenish to reddish pelagic claystones in the interval from 603B-41-4, to 603B$38-3$, and is of Albian age. Subunit IVA, the highest of the Hatteras Formation, is the thickest $(47.4 \mathrm{~m}$, or about $49.6 \%$ of the formation). It consists of organic-matterrich, black claystones and greenish gray, pelagic claystones lacking any reddish color, ranges from 603B-38-2 to the top of the formation at $603 \mathrm{~B}-33-1,60 \mathrm{~cm}$, and is primarily of Cenomanian age.

The organic matter in the two more carbonaceous subunits of the Hatteras Formation is evidently of different origins. That of Subunit IVC is predominantly terrigenous, whereas that of Subunit IVA is predominantly pelagic. The pelagic facies of the organic residues in Subunit IVA correlates in age with the Cenomanian marinecarbon-rich sapropels at other sites in the North Atlantic (Ryan and Cita, 1977). The organic matter in the alternating pelagic claystone subunits is similar in its small residues, consisting of poorly preserved pelagic debris, and also in the occurrence of samples barren of palynomorphs but containing small, angular, carbonized particles (micrinite) which are considered to be at least in part of diagenetic origin. Subunit IVD correlates in age with Aptian "red clays" recovered at Site 534 in the BlakeBahama Basin (Habib, 1983; Habib and Drugg, 1983).

\section{Plantagenet Formation}

This formation was defined for noncalcareous, variegated pelagic claystones overlying the Hatteras Formation (Jansa et al., 1979). At Site 603, the Plantagenet Formation (Unit III) is approximately $97 \mathrm{~m}$ thick, and extends from 603B-33-1, $60 \mathrm{~cm}$ to $603 \mathrm{~B}-22-2,68 \mathrm{~cm}$. Three subunits were distinguished, based on the relative abundance of brownish and greenish claystones and the appearance of carbonaceous claystone. The occurrence of carbonaceous claystone, and of terrigenous silt and sand in all three subunits, is reported for the first time from the Plantagenet Formation (Site 603 chapter, this volume). Subunit IIIC consists of predominantly red- 
dish brown, variegated claystone in the interval from 603B$33-1,60 \mathrm{~cm}$ to $603 \mathrm{~B}-29-3$. Samples investigated from this interval contain micrinite but are barren of palynomorphs. Subunit IIIB, from 603B-29-2 to 603B-24, also consists of variegated claystones, with the greenish gray claystones predominating. There is now some dark gray carbonaceous claystone present. Study of the samples in Cores 603B-28 and 603B-26 indicate that the organic matter is predominantly terrigenous, and the dinoflagellates indicate a range in age from the late Coniacian to Santonian. Subunit IIIA, from 603B-23,CC to the top of the formation in 603B-22-2, $68 \mathrm{~cm}$, is similar in lithology to Subunit IIIC and is barren of palynomorphs in organic residues that consist of micrinite or poorly preserved amorphous debris.

\section{Distribution of Major Palynomorph Groups}

Palynomorphs or other organic particles occur in all of the investigated samples. Land plant spores and pollen grains (sporomorphs) are numerically abundant in terrigenous clays and silty clays, and dinoflagellate specimens (dinocysts) occur in higher relative percentages in some pelagic lithologies, although they only rarely become numerically abundant. Samples that are barren of palynomorphs (Appendix A) nevertheless contain at least some residue, composed mostly of micrinite.

The single most abundant group of palynomorphs at Site 603, as elsewhere in the North Atlantic, is represented by pollen grains in Classopollis, Pinuspollenites, and Alisporites. In Hole 603B, these sporomorphs collectively reach up to $75 \%$ of all palynomorphs in terrigenous clays containing up to approximately 50,000 specimens/g, up to $82 \%$ in pelagic clays containing up to approximately 15,000 specimens/g, and up to $78 \%$ in pelagic clays containing fewer than 500 specimens $/ g$. Despite these high percentages in both highly and poorly fossiliferous samples, this group's stratigraphic and sedimentological value is limited. The bisaccate grains of Pinuspollenites and Alisporites and the small spheroidal grains of Classopollis, together with their abundance in both marine and nonmarine sediments of Early Cretaceous age, indicate that they were produced in large numbers by anemophilous conifers with morphologies adapted for buoyancy and widespread distribution. In effect, they were transported where marine currents would flow, whether these pollen grains were introduced by streams or by the winds; they are the "wind-blown" pollen grains.

In contrast to these sporomorphs, another group of sporomorphs is considered to be sedimentologically significant. This group is represented by the larger $(>50 \mu \mathrm{m})$ and/or highly structured and ornamented pteridophyte spores that are attributed mostly to the ferns and to a lesser extent to the club mosses. These lower vascular plant spores include species in genera such as, for example, Cicatricosisporites, Costatoperferosporites, Appendicisporites, Pilosisporites, Concavissimisporites, Converrucosisporites, Trilobosporites, and Densoisporites. The stratigraphic distribution of these spores is not continuous, but is episodic. They are associated in larger numbers and diversity with terrigenous turbiditic intervals at Site 603, as they are elsewhere near North Atlan- tic margins (Habib, 1982a). Their close association with well-preserved tracheids and other vascular tissue, megaspores, and fern sporangial tissue indicates more localized and more rapidly sedimented terrigenous organic matter, such as that discharged by streams and distributaries, and by turbidity currents.

Other sporomorphs occur in minor amounts throughout the section in both terrigenous and pelagic intervals. These include the smaller pteridophyte spores in genera such as Cyathidites, Gleicheniidites, and Deltoidospora, and smaller pollen grains in Exesipollenites, Cerebropollenites, Callialasporites, Vitreisporites, and Cycadopites. They are considered to be of little stratigraphic and sedimentological value.

The marine microflora is represented by dinoflagellate species. Dinocysts occur in every sample in the investigated section that contains palynomorphs. These specimens compose approximately 10 to $15 \%$ of all palynomorphs in most samples, depending on the abundance of classopollid and bisaccate pollen. However, the number of dinoflagellate species may vary considerably. Elsewhere in the western North Atlantic (Habib, 1977; Habib and Drugg, 1983), dinoflagellate species are few across the Jurassic/Cretaceous boundary and are stratigraphically discontinuous for the most part. By the late Berriasian, at Site 603 and at other sites that have been previously studied, there is a major influx of species, many of which first appear in the Cretaceous. Figure 2, in the back pocket, shows this influx of species and the net increase of species through the Neocomian stages. A similar distribution of species is evident in the stratotype dinoflagellate stratigraphy of Tethyan Neocomian stages of Europe (Habib and Drugg, 1983). Species continue to appear first in the Barremian, but by the late Barremian-Aptian interval there is an episode of apparent extinctions which interrupts the trend of increasing numbers of species per stage (Fig. 2). The largest number of species per stage occurs in the Albian, where there is an association of species which have first and last appearances. This trend in species abundance corresponds fairly closely to the global trend of dinoflagellate species abundance compiled by Bujak and Williams (1979, table 2 ; figs. 5 and 8 ). These authors show a smaller number of species in the approximate position of the Jurassic/Cretaceous boundary, and then a trend toward an increased number of species through the Early Cretaceous, with a maximum number in the Albian.

This apparent correlation suggests that dinoflagellate species abundance was not controlled by any event unique to the Cretaceous North Atlantic. Rather, it may have been a response to the generally progressive rise in global sea level (with intervening sea level falls) during the Early Cretaceous. The accompanying marine transgressions would have provided additional habitats which would have accommodated additional species in the expanding continental shelf environments that the cyst-producing (and thus, fossil-producing) meroplanktonic dinoflagellate flora occupied. A major influx of additional species occurred in the late Albian, signalling the beginning of the largest marine transgression of Cenomanian age to affect the continents bordering the North Atlantic, at a 
time when the geographically extensive marine-carbonrich sapropels were being deposited in the North Atlantic.

Small acritarchs are ubiquitous in the investigated section, and are numerically abundant in some samples. Their stratigraphy at Site 603 has not been studied.

\section{Dinoflagellate Stratigraphy}

The dinoflagellate zonation of the western North Atlantic in the Early Cretaceous is based to a large extent on the ranges of species of Biorbifera (B. johnewingii) and Druggidium (D. apicopaucicum, D. deflandrei, and $D$. rhabdoreticulatum), for the following reasons. First, these species are stratigraphically very persistent throughout their respective ranges and often are the dominant dinocysts in the samples. Their stratigraphic persistence is frequently demonstrated by their occurrence in samples which contain few dinocysts of any kind. Also, at sites drilled far from the present continental margin (e.g., Site 387 on the Bermuda Rise), specimens of Biorbifera and Druggidium actually increase in percentage relative to other dinocysts (Habib, 1979a). Thus, throughout their range in the western North Atlantic, from Sites 105 and 603 in the north to Site 99 in the south, and from Site 534 in the west to Site 387 in the east (Fig. 1), these species appear to be the most reliable fossils for zonation because of their stratigraphic persistence and relative abundance.

Their value in biostratigraphic dating, especially in the Neocomian (Berriasian-Hauterivian), is evident from their precise correlation with the corresponding stage stratotype (and ammonite-dated parastratotype) dinoflagellate stratigraphy of southeastern France and western Switzerland. These stratotype sections lie within the Cretaceous Tethyan province of southern Europe. Their correlation with the European Tethys is remarkably close, not only with respect to the stratigraphic ranges of these and other species, but also in the relative abundance of specimens in the two areas. Clearly, these two genera are best represented in the Tethys, and it is most likely that the biostratigraphy established from them will be most valuable in the study of Tethyan sections of Early Cretaceous age. Both Biorbifera and Druggidium do occur in the Boreal Province of England and West Germany, but they are rare and their ranges are stratigraphically discontinuous. Significantly, however, they do occur within their Tethyan-defined ranges. Biorbifera also occurs in the offshore area of southeastern Canada (Williams, 1975), in the Sacramento Valley of California (Habib and Warren, 1973), and in Australia (R. Helby, 1983, personal communication). Druggidium (D. deflandrei, D. rhabdoreticulatum) has been reported from the offshore Cretaceous of the western margin of Australia in Deep Sea Drilling Project cores (Wiseman and Williams, 1974; Morgan, 1980). D. apicopaucicum and B. johnewingii also occur in the eastern North Atlantic, in sediments dated as Valanginian in age (Habib, 1982a). Both $D$. deflandrei and $D$. rhabdoreticulatum occur in the stratotype Barremian at Angles in a mixed Tethyan/cosmopolitan association (DeRenéville and Raynaud, 1981; Habib and Drugg, 1983), and D. deflandrei occurs in North
Atlantic sediments dated Aptian by calcareous nannofossils (Roth and Thierstein, 1972).

The stratigraphic disparity in abundance of Tethyan and Boreal dinoflagellate taxa was emphasized by DeRenéville and Raynaud (1981). In their study of Lower Cretaceous Stage stratotype sections in Europe, these authors independently confirmed the relative abundance of Biorbifera and Druggidium in Tethyan Neocomian stages, and their paucity and/or absence in the Boreal Province. As an example of a species in which the reverse is true, DeRenéville and Raynaud (1981) state that Sirmiodinium grossii Alberti is a long-ranging and commonly occurring species in the Boreal Upper JurassicLower Cretaceous, but is rare or absent in contemporaneous Tethyan sections. In the western North Atlantic, this species has thus far been observed only in the Upper Jurassic, and only by its pentagonal morphotype (Habib and Drugg, 1983).

These observations argue for separate dinoflagellate zonations for the Boreal and Tethyan Upper JurassicLower Cretaceous. Each zonation would ultimately be dated by ammonites diagnostic in its own province. Notwithstanding the provincially controlled distributions of Druggidium and Biorbifera, their chronostratigraphic value in the western North Atlantic is evident by their direct correlation with the European stratotype stratigraphy. Correlation of the Tethyan zonation with dinoflagellate zonations outside this province can be established by utilizing the less frequently occurring species common to both areas.

The dinoflagellate zonation at Site 603 is dated by correlation with the stratotype stratigraphy of western European. Correlation with ammonite zones is made with reference to the Neocomian stratotype zonation published by Habib and Drugg (1983). The definition of the zones is the same as that published by Habib (1977) and Habib and Drugg (1983), except that at Site 603 the upper boundary of the Trithyrodinium suspectum Zone can now be defined. Reference to the European sections that were investigated is given in Habib and Drugg (1983). Figure 2 shows the dinoflagellate stratigraphy and zonation prepared for Hole 603B, as well as the magnetostratigraphic polarity scale prepared for this section by Ogg (this volume). According to Ogg (this volume), the dinoflagellate zonation and the polarity stratigraphy are precisely correlated between Sites 534 (Habib and Drugg, 1983) and 603 (Fig. 1). This evidence indicates that the zonation is synchronous through at least a large part of the western North Atlantic.

\section{DINOFLAGELLATE ZONES, SITE 603}

\section{Biorbifera johnewingii Zone}

Definition. Interval from the first appearance of $B$. johnewingii to the first appearance of Druggidium apicopaucicum. At Site 603, this zone extends from Samples 603B-82-5, 51-53 cm to 603B-80-1, 20-22 $\mathrm{cm}$.

Age. Late Berriasian. In the European stratotype dinoflagellate stratigraphy, this zone covers the interval within the Berriasella boisseri ammonite Zone from the Dalmasiceras dalmasi Subzone to the top of the Berriasian.

Remarks. This zone is approximately $27 \mathrm{~m}$ thick at Site 603 and represents the lowest sediment recovered at this location during Leg 
93. The major lithology is nannofossil claystone and limestone. The samples (Appendix A) contain many well-preserved dinoflagellate cysts in an organic matrix dominated by amorphous debris. Throughout the zone, the most commonly occurring species are Cometodinium whitei (Deflandre and Courteville) and B. johnewingii. In Core 603B82 , other commonly occurring species include Diacanthum hollisteri Habib (auct. non Occisucysta evittii [Dodekova] Gitmez sensu Below, 1982) and Amphorula metaelliptica Dodekova. A. metaelliptica is restricted to this core. Other species which first appear in this zone at Site 603 include Ctenidodinium elegantulum Millioud, Hystrichodinium pulchrum Deflandre (as H. voigtii [Alberti] in Habib and Drugg, 1983), Wallodinium krutzschii (Alberti), Scriniodinium campanulum Gocht, Cyclonephelium distinctum Deflandre and Cookson, Gonyaulacysta helicoidea (Eisenack and Cookson), Polysphaeridium warrenii Habib, Muderongia simplex Alberti, and Dingodinium cerviculum Cookson and Eisenack, among others (Fig. 2). Phoberocysta neocomica (Gocht) was found in only one sample in this zone, 603B-81-1, 19-21 cm. The very bottom sample, 603B-82-5, 51-53 cm, contains Pseudoceratium pelliferum Gocht and Prismatocystis cylindrica Habib, which suggests that the bottom of the section at Site 603 lies within the upper part of the Biorbifera johnewingii Zone, and close to the Berriasian/Valanginian boundary. The most commonly occurring sporomorphs in the zone include bisaccate pollen grains and Classopollis.

\section{Druggidium apicopaucicum Zone}

Definition. Interval from the first appearance of the nominative species to the phylogenetic appearance of $D$. deflandrei (Millioud). It extends from Sample 603B-79-7, 0-2 cm to 603B-76-5, 19-21 cm.

Age. Earliest Valanginian to early late Valanginian. In the European sections, this zone ranges from the base of the Thurmanniceras pertransiens ammonite Zone into the Saynoceras verrucosum ammonite Zone. The first appearance of $D$. apicopaucicumis taken to represent strata immediately above the Berriasian/Valanginian boundary, by correlation with the stratotype stratigraphy.

Remarks. This zone is approximately $28 \mathrm{~m}$ thick at Site 603 . The major lithology is organic-matter-bearing nannofossil chalk, which may be interbedded with nannofossil limestone. The organic facies is the same as that which characterizes the underlying Biorbifera johnewingii Zone. Most of the species which first appear in the lower zone range through the Druggidium apicopaucicum Zone. An important exception is $D$. hollisteri, which last appears in the lowest sample of the zone. Elsewhere in the western North Atlantic, and in the stratotype stratigraphy, this species ranges through the $D$. apicopaucicum Zone.

\section{Druggidium deflandrei Zone}

Definition. Interval from the phylogenetic appearance of $D$. deflandrei to the phylogenetic appearance of $D$. rhabdoreticulatum. At Site 603, it ranges from Sample 603B-75-5, 50-52 cm to 603-63-6, $74-76 \mathrm{~cm}$.

Age. Late Valanginian to Hauterivian (probably late Hauterivian). The lower boundary of this zone lies within the Himantoceras trinodosum ammonite Zone in southern Europe. The overlying Druggidium rhabdoreticulatum Zone from the western North Atlantic has not been recognized in the Neocomian stratotype stratigraphy of southern Europe, where the $D$. deflandrei Zone apparently ranges directly up to the next overlying Odontochitina operculata Zone. The Valanginian/ Hauterivian boundary at Site 603 is placed between Samples 603B$72, \mathrm{CC}$ and $603 \mathrm{~B}-71-6,3-5 \mathrm{~cm}$, directly above the last appearance of Scriniodinium dictyotum Cookson and Eisenack. In the stratotype stratigraphy, this species last appears in the Neocomites callidiscus Zone, the highest ammonite zone (subzone) of the Valanginian.

Remarks. The Druggidium deflandrei Zone is approximately $116 \mathrm{~m}$ thick. The lower part of the zone (Valanginian) is characterized by the first major influx of abundant terrigenous organic matter which recurs in the upper part. This event compares closely with the lowermost occurrence of graded, silty claystones in Section 603B-76-1; these continue upsection in a lithology of silty claystones, fine sandstones, and clay-bearing nannofossil limestones.

B. johnewingii last appears in the lower (Valanginian) part of the zone. Species which first appear in this part include Cassiculosphaeridia magna Davey, Lithodinia stoveri (Millioud), Oligosphaeridium asterigerum (Gocht) (or $O$. complex [White]), O. abaculum Davey, and O. pulcherrimum (Deflandre and Cookson). Dingodinium cerviculum becomes stratigraphically persistent at the base of the zone. Other species first appear in the upper (Hauterivian) part of the zone. Hystrichosphaerina schindewolfii Alberti was observed in Sample 603B-71-6, $3-5 \mathrm{~cm}$ only. Other species which first appear in the Hauterivian include Cribroperidinium edwardsii (Cookson and Eisenack). Subtilisphaera perlucida (Alberti) and Callaiosphaeridium asymmetricum (Deflandre and Courteville). Other species which occur in this zone include Aprobolocysta varigranosa Duxbury and Batioladinium micropodum (Eisenack and Cookson).

\section{Druggidium rhabdoreticulatum Zone}

Definition. Interval from the phylogenetic appearance of the nominative species to the first appearance of Odontochitina operculata. At Site 603, it ranges from Samples 603B-62, 60-62 cm through 603B-60-4, $16-18 \mathrm{~cm}$.

Age. Hauterivian (probably late Hauterivian). This zone is not recognized outside the western North Atlantic. The evidence of its probable late Hauterivian age is drawn from the first appearance in Sample 603B-60-4, 16-18 cm of Muderongia tetracantha (Gocht). In the stratotype stratigraphy, this species first appears in the late Hauterivian.

Remarks. This zone is approximately $28 \mathrm{~m}$ thick. Despite its lack of identification in the stratotype stratigraphy, it is considered to be valuable because of its geographic range in this area. For example, it has been distinguished at Sites 534, 391, 105, and 387.

\section{Odontochitina operculata Zone}

Definition. Interval from the first appearance of the nominative species to the last appearance of Phoberocysta neocomica. At Site 603 , this zone ranges from Samples 603B-59-5, 103-105 cm through 603B-46-4, 30-32 cm.

Age. Late Hauterivian to earliest Aptian (early Bedoulian). In the stratotype stratigraphy, $O$. operculata first appears in the late Hauterivian Subsaynella sayni ammonite Zone. P. neocomica last appears near the base of the Bedoulian Substage of the Aptian in the stratotype section at LaBedoule and in the basal Aptian in the Barremian stratotype section at Angles. The Hauterivian/Barremian boundary is distinguished between samples 603B-57-6, 27-29 cm and 603B-56-3, $81-83 \mathrm{~cm}$ by the last appearance of $D$. apicopaucicum in the former sample. The Barremian/Aptian boundary is placed between Samples $603 \mathrm{~B}-47-1,80-82 \mathrm{~cm}$ and $603 \mathrm{~B}-46-4,30-32 \mathrm{~cm}$ by the last appearance of $P$. neocomica in the latter sample. The boundary between the early and late Barremian is tentatively placed within the interval from Sample 603B-53-6, 35-37 cm or 603B-52-7, 38-40 cm (based on the last appearances of Muderongia tetracantha in former sample and Cassiculosphaeridia magna in the latter) to 603B-49-1, 120-122 cm, based on the first appearance of Prolixoshaeridium parvispinum (Cookson and Eisenack) in this sample. According to DeRenéville and Raynaud (1981), M. tetracantha and C. magna last appear in the early Barremian in the stratotype Angles section, and $P$. parvispinum first appears in the late Barremian.

Remarks. The Odontochitina operculata Zone is approximately $116 \mathrm{~m}$ thick, of which approximately $97 \mathrm{~m}$ (Samples 603B-56-3, 81-83 $\mathrm{cm}$ to $603 \mathrm{~B}-47-1,80-82 \mathrm{~cm}$ ) represent the Barremian Stage. The organic facies is terrigenous in the lower (late Hauterivian-early Barremian) and upper (Bedoulian Aptian) parts of the zone. The middle part contains poorly preserved amorphous debris, although within this interval also there are episodes of terrigenous influx of organic matter. The major lithologies of this part of the section range from fine sandstones and silty sandstones in the lower part, to interbedded claystones and silty sandstones and nannofossil limestones in the middle part, to sandstones and loosely consolidated sands in the upper part.

Bourkidinium sp. (Plate 4, Fig. 10) was observed in Samples 603B$58-6,65-67 \mathrm{~cm}$ and $603 \mathrm{~B}-61-6,69-71 \mathrm{~cm}$ and also in a single sample from Site 105, Sample 105-18-4, 138-140 cm. Despite these restricted occurrences, this species may have stratigraphic value, since it is known to occur in the late Hauterivian of France (Crioceras duvali ammonite Zone to the top of the Hauterivian). At both Sites 603 and 105, it occurs near the base of the $O$. operculata Zone.

The last appearance of the stratigraphically persistent Druggidium apicopaucicum is significant for recognizing the Hauterivian/Barremian boundary throughout western North Atlantic and in the stratotype stratigraphy. At Site 603, this species was observed again in Sample $603 \mathrm{~B}-50-1,58-60 \mathrm{~cm}$. A similar stratigraphic gap exists at Sites 534 
and 391 in the Blake-Bahama Basin. Habib and Drugg (1983) attributed this anomalous occurrence at Site 534 to recycling, since this species does not occur in Barremian or younger sediments elsewhere in the North Atlantic or in the stratotype stratigraphy.

Species which first appear in the lower part of this zone include Subtilisphaera terrula (Davey) and Coronifera oceanica Cookson and Eisenack. At both Sites 603 and 534, C. oceanica first appears at the Hauterivian/Barremian boundary. However, in the stratotype area, this species is known to appear in the late Hauterivian. The bisaccate pollen species Rugubivesiculites reductus Pierce and reticulate monocolpate pollen in the genus Clavatipollenites first appear in the middle part of the interval dated Barremian. Species which first appear in the upper part of the zone include Gradodinium eisenackii Alberti, $\mathrm{Pa}$ laeoperidinium cretaceum Pocock, and Cassiculosphaeridia reticulata Davey.

Neocomian species which last appear within the Barremian include Muderongia simplex, Ctenidodidium elegantulum, and Prismotocystis cylindrica.

\section{Subtilisphaera perlucida Zone}

Definition. Interval from immediately above the last appearance of Phoberocysta neocomica to the first appearance of Spinidinium vestitum Brideaux. At Site 603, this zone ranges from Samples 603B$46-2,143-145 \mathrm{~cm}$ to $603 \mathrm{~B}-40-5,10-12 \mathrm{~cm}$.

Age. Aptian to early or middle Albian. The Aptian/Albian boundary is distinguished within the zone immediately above the last appearance of Druggidium deflandrei, between Samples 603B-43-4, 63-65 $\mathrm{cm}$ and $603 \mathrm{~B}-43-1,6-8 \mathrm{~cm}$, by correlation with the stratotype stratigraphy. The boundaries between the early and late Aptian, and between early and middle Albian, have not been recognized.

Remarks. The Subtilisphaera perlucida Zone represents the transition from the Aptian to the Albian and from the lower turbiditic sandstones and claystones to the upper interval of predominantly reddish brown claystones interbedded with predominantly black carbonaceous claystones. It is approximately $53 \mathrm{~m}$ thick. The interval characterized by samples $603 \mathrm{~B}-46-2,143-145 \mathrm{~cm}$, to $603 \mathrm{~B}-44-2,50-52 \mathrm{~cm}$ contains relatively well preserved palynomorphs and a variety of tracheal and other cellular tissue. Beginning with sample 603B-44-1, 43-45 cm, the residues consist for the most part of poorly preserved palynomorphs and relatively little amorphous debris. This continues to the stratigraphic level of 603B-43-2, 22-24 cm. Several samples in this interval are barren of palynomorphs and contain nothing but carbonized fine particles (Appendix A). Samples in the interval from 603B-43-1, 6-8 $\mathrm{cm}$ to the top of the zone in $603 \mathrm{~B}-40-5,10-12 \mathrm{~cm}$ are in part fossiliferous again, but in a facies that varies from carbonized tracheal tissue to poorly preserved amorphous debris. This interval also is characterized by barren samples.

The nominative species, $S$. perlucida, ranges through the zone. Neocomian species which last appear in the lower, Aptian, part of this zone include Pseudoceratium pelliferum and Wallodinium krutzschii. Other species which have stratigraphically persistent last appearances in the underlying Odontochitina operculata Zone occur within single samples in the S. perlucida Zone. These include Druggidium rhabdoreticulatum, which is represented in Sample 603B-44-4, 50-52 cm by a single specimen, and Polysphaeridium warrenii, which is represented in Sample 603B-45-1, 98-100 cm by a single specimen. Sample 603B-46-2, 143-145 cm contains specimens referable to Muderongia cf. $M$. simplex. They are distinguished from $M$. simplex by being smaller and possessing less well developed lateral horns. The spore species Pilosisporites trichopapillosus (Thiergart) last appears in this sample.

Hapsocysta peridictya (Eisenack and Cookson) first appears in the Aptian within the $S$. perlucida Zone. $D$. deflandrei is stratigraphically persistent through the poorly fossiliferous interval, and last appears in Sample 603B-43-4, 63-65 cm. Samples 603B-43-4, 134-136 cm and 603B-43-2, 22-24 cm are barren. However, Sample 603B-43-1, 6-8 cm contains a diversified palynomorph assemblage and carbonized tracheal tissue in a quartz-bearing terrigenous claystone of Albian age. Litosphaeridium arundum (Eisenack and Cookson) first appears in this sample, and ranges to near the top of the Albian in Sample 603B$39-5,57-59 \mathrm{~cm}$. At Site 534, this species first appears in the fossiliferous sample just below the Aptian/Albian boundary. Samples 603B$43-1,6-8 \mathrm{~cm}$ and $603 \mathrm{~B}-42-6,37-39 \mathrm{~cm}$ contain numerous specimens of Cyclonephelium distinctum Deflandre and Cookson, including some which are tabulated. In this respect, the palynostratigraphic transition across the Aptian/Albian boundary is remarkably similar to that at Site 534 . At both sites, $D$. deflandrei last appears in a poorly fossiliferous interval, is followed by a short interval of barren samples, and then by a lowermost Albian interval that is fossiliferous and contains much carbonized tracheal tissue and assemblages dominated by morphotypes in $C$. distinctum.

\section{Spinidinium vestitum Zone}

Definition. Interval from the stratigraphic first appearance of the nominative species to the phylogenetic appearance of Spinidinium echinoideum (Cookson and Eisenack). At Site 603, this zone extends from Samples 603B-40-3, 33-35 cm to 603B-39-2, 50-52 cm.

Age. Middle or late Albian to late Albian.

Remarks. At Site 603, this zone is relatively thin, approximately 18 $\mathrm{m}$, in a lithology of reddish brown to greenish gray claystones and black to greenish black claystones. In all five samples representing the Spinidinium vestitum Zone, dinoflagellate species are more numerous than sporomorph species and are represented by more specimens than sporomorphs, in a residue consisting mostly of poorly preserved amorphous debris. Sporomorphs are represented by small percentages of Classopollis, bisaccate pollen grains, and the smaller pteridophyte spores.

Many dinoflagellate species first appear within the Spinidinium vestitum Zone and in the late Albian of France. These include Epelidosphaeridia spinosa (Cookson and Hughes), Leberidocysta chlamydata (Cookson and Eisenack), L. defloccata (Davey and Verdier), Litosphaeridium siphoniphorum glabrum Lucas-Clarke, Palaeohystrichophora infusorioides Deflandre, Dinopterygium cladoides Deflandre, Xiphophoridium alatum (Cookson and Eisenack), Xenascus ceratioides (Deflandre), and Subtilisphaera pontismariae (Deflandre). This zone also contains the oldest triaperaturate angiosperm pollen species in the western North Atlantic, including Tricolpites minutus (Brenner), Retitricolpites georgensis Brenner, R. sphaeroides Pierce, and Psilatricolporites sp. (Habib, 1978, plate 1, fig. 8).

Several dinoflagellate species last appear within this zone, including Subtilisphaera perlucida and S. terrula.

\section{Spinidinium echinoideum Zone}

Definition. Interval from the phylogenetic appearance of the nominative species to the stratigraphic first appearance of Trithyrodinium suspectum (Manum and Cookson). At Site 603, this zone ranges from Samples 603B-38-5, 54-56 cm to 603B-36-3, 53-55 cm.

Age. Latest Albian (Vraconian) to Cenomanian. The Albian/Cenomanian boundary is distinguished between Samples 603B-38-3, 35$37 \mathrm{~cm}$ and $603 \mathrm{~B}-37-5,68-70 \mathrm{~cm}$, based on the first appearance of the Normapolles pollen genus Complexiopollis in the latter sample.

Remarks. The Spinidinium echinoideum Zone is approximately $18 \mathrm{~m}$ thick in a lithology of black carbonaceous and pelagic greenish gray claystones. The organic facies is the same as that of the underlying $S$. vestitum Zone. All of the species which first appear in the underlying zone range through this zone. Wallodinium inflatum Habib, first appears at the base. The $S$. echinoideum Zone documents the diversification of angiosperm pollen morphotypes. Smaller prolate to subprolate tricolpate grains in Retitricolpites and the small oblate tricolporate species in Psilatricolporites range through the zone. In the Cenomanian interval, they are joined by Complexiopollis, Atlantopollis, and larger spheroidal tricolporate grains with deeply incised furrows in polar view.

\section{Trithyrodinium suspectum Zone}

Definition. Interval from the stratigraphic first appearance of $T$. suspectum to the last appearance of Litosphaeridium siphoniphorum glabrum. At Site 603, this zone ranges from Samples 603B-36-1, 105$107 \mathrm{~cm}$ to $603 \mathrm{~B}-34-1,70-72 \mathrm{~cm}$. Elsewhere in the western North Atlantic, the upper boundary of this zone was not defined (Habib, 1977). It is defined herein by the highest stratigraphic occurrence of $L$ siphoniphorum glabrum in a fossiliferous interval.

Age. Cenomanian (?-basal Turonian). Foucher (in Robaszynski et al., 1982) indicates that $L$. siphoniphorum normally last appears in the Cenomanian, but that it does occur in the basal Turonian in the stratotype area of Samurois. 
Remarks. This zone, approximately $18 \mathrm{~m}$ thick at Site 603 , occurs in black, organic-matter-rich samples, some of which are finely laminated and others apparently burrowed. Organic matter is abundant in all of the six samples representing this zone that were investigated. The residue consists almost entirely of well-preserved amorphous debris including many larger aggregates, some of which are in the form and size of zooplanktonic fecal pellets (Habib, 1982b, plate 1, fig. 2). As in the underlying two zones defined by Spinidinium, dinocysts are more numerous than sporomorphs and the latter are represented by angiosperm pollen and the smaller pteridophyte spores. The main difference is that the amorphous debris is well preserved in the Trithyrodinium suspectum Zone and is more abundant.

T. suspectum is restricted to this zone at Site 603, but ranges from the lowermost sample to the uppermost. Wallodinium inflatum last appears within this zone. The new genus and species, Pierceites schizocystis, was observed in Sample 603B-34-6, 15-17 cm only. Gonyaula cysta cassidata (Eisenack and Cookson) also occurs in this sample.

Samples from Core 603B-33 contain an abundant organic residue of well-preserved amorphous debris and relatively few palynomorphs. These include Subtilisphaera pontismariae, Palaeohystrichophora infusorioides, Dinopterygium cladoides, Odontochitina operculata, and Spiniferites cingulatus (Wetzel). The samples may be of post-Cenomanian age, because $L$. siphoniphorum glabrum is absent. This sub-species is persistent in its stratigraphic range through the Spinidinium vestitum-Trithyrodinium suspectum zones. Atlantopollis sp. occurs in Sample 603B-33-1, 80-82 cm, which suggests that this stratigraphic level is not younger than Turonian.

Samples from Core 603B-32 through Sample 603B-29-2, 45-47 cm are essentially devoid of palynomorphs. The residue consists of black carbonized particles in a lithology of greenish gray to brown variegated claystones.

The interval from Samples 603B-28-4, 96-98 cm to 603B-26-4, $27-$ $29 \mathrm{~cm}$ is considered to range from late Coniacian or early Santonian to Santonian. Odontochitina porifera Cookson, which occurs in both samples, ranges from just below the Coniacian/Santonian boundary to just above the Santonian/Campanian boundary. Other species which occur in both samples include Alterbia acuminata (Cookson and Eisenack), Palaeoperidinium pyrophorum (Ehrenberg), Dinogymnium acuminatum Evitt, Clarke, and Verdier, and Senoniasphaera protrusa Clarke and Verdier. The presence of $S$. protrusa suggests that this interval is not younger than Santonian. The presence of $D$. acuminatum suggests an age not older than late Coniacian. Sample 603B-28-4, 96$98 \mathrm{~cm}$ also contains Dinopterygium cladoides and Xiphophoridium alatum, which suggests an age not younger than early Santonian. Aldorfia deflandrei (Clarke and Verdier), the angiosperm pollen "Retitricolpites M" of Wolfe (1976), and the acritarch Schizocystia laevigato Cookson and Eisenack occur in Samples 603B-26-4, 27-29 cm. The presence of "Retitricolpites M" suggests a Santonian age.

\section{Stratigraphic Distribution of Organic Facies}

The sedimentological control of palynologically defined organic facies was proposed originally from study of these facies at Site 398, adjacent to the Iberian Peninsula, where they were compared directly with the sedimentary facies in that section (Habib, 1979b) and with the independently determined geochemical evidence of the abundance and origin of the organic carbon (Deroo et al., 1978). Subsequent study of additional sections drilled by the Deep Sea Drilling Project showed a sequential alteration of terrigenous and pelagic organic facies through the Berriasian-Cenomanian interval, and also a spatial distribution which showed that the terrigenous character decreases away from the margins bordering the Cretaceous North Atlantic (Habib, 1982a, b).

Abundant terrigenous matter defines the exinitic and tracheal facies. The former contains palynomorphs in the order of $60,000-100,000 / \mathrm{g}$, with sporomorphs comprising more than $90 \%$ of all specimens. The larger spores are always best expressed in this facies and are always associated with numerous well-preserved tracheids. At Site 398, the facies occurs in Barremian, early Aptian, and early Albian turbiditic clays in a submarine fan complex, which geochemical study indicates is mostly of terrestrial origin. This facies also occurs in prodeltaic clays off the North African margin (Habib, 1982a, after von Rad, Ryan, et al., 1979). It is now known to occur in a submarine fan setting in the western North Atlantic, at Site 603. The tracheal facies is similar, except that it contains fewer larger spores and palynomorphs in the order of $40,000-60,000 / \mathrm{g}$. This facies occurs in graded and cross-laminated terrigenous clays and clay turbidites; it occurs in submarine fan settings and also within distal turbidite intervals in ancient abyssal plains.

The pelagic, or xenomorphic, organic facies is characterized by abundant fine, granular amorphous particles which are estimated to comprise approximately $75 \%$ to more than $90 \%$ of the organic residues. The debris is so abundant that it commonly occurs in aggregates which obscure the presence of palynomorphs. The pelagic origin of at least most of this debris is derived from the common occurrence in this facies of elongate ellipsoidal bodies, consisting of the same amorphous debris, which are quite close to the composition, shape, and size of fecal pellets produced by modern zooplankton fed a diet of phytoplankton (Habib, 1982b, after Porter and Robbins, 1981). Geochemical evidence in support of this conclusion is drawn from the analysis of Cenomanian sapropels at Sites 398 and 105, which shows the organic carbon to be primarily of marine origin. Amorphous debris may also occur in the terrigenous facies, but it is not nearly so abundant as it is in the xenomorphic facies. Dinocysts are well preserved and usually occur in high relative percentages, depending on the occurrence of classopollid and bisaccate pollen grains. Although dinocysts are usually not numerically abundant, they are commonly represented by a larger number of dinoflagellate species. At Site 535 in the southeastern Gulf of Mexico, Riley and Fenton (1984) describe the organic matter recovered from the section of Early Cretaceous age to consist predominantly of amorphous debris, dinocysts, Classopollis, and bisaccate pollen. This organic matter is typical of the xenomorphic facies.

The last category is characterized by carbonized particles of vascular tissue. Recognizable carbonized tracheids occur with well-preserved tracheids in the tracheal and exinitic facies. In these facies, it is evident that they have been recycled. Carbonized tracheids are also concentrated in samples that are impoverished or barren of palynomorphs. These tracheids may have been recycled, but the paucity of other organic particles and their presence in black clays occurring within hematitic variegated clay intervals at Site 603 suggest that they are the residue of terrigenous organic matter oxidized in the buried sediment. At Site 534 in the Blake-Bahama Basin, these tracheids are concentrated in Jurassic blackish red clays that are bioturbated (Habib, 1983). Other carbonized particles are finer-grained, opaque, and black. They are concentrated in the micrinitic facies. Micrinite is ubiquitous in the other organic facies. It is common constituent of the tracheal and exinitic facies, where it is evi- 
dently recycled. It also occurs in xenomorphic facies, where the amorphous debris is poorly preserved by virtue of its brownish color. Poorly preserved fecal pellets in these residues also contain micrinite, which suggests that in this case the micrinite may have been produced as the result of oxidation of fecal pellets in the buried sediment.

At Site 603, organic-stratigraphic units are defined for stratigraphic intervals characterized by a predominantly occurring organic facies. Appendix B summarizes the characteristics of these units, and their distribution is illustrated in Figures 2 and 3. Terrigenous facies are labelled KT1, KT2, et seq., indicating that the first, or lowermost, Cretaceous unit, KT1, is followed by the subsequent, or next higher, Cretaceous unit (KT2) dominated by terrigenous organic matter. The alternating units dominated by pelagic amorphous debris are labelled $\mathrm{KX} 1$, $\mathrm{KX} 2$, et seq. as defined by the predominantly occurring xenomorphic facies in these units. Three intervals, those between $\mathrm{KX} 3$ and $\mathrm{KT} 3$, between $\mathrm{KT} 4$ and $\mathrm{KX} 5$, and between KX5 and KT5(CT) are not labelled in any sequential order as they are dominated by the micrinitic facies and contain few, poorly preserved palynomorphs or are palynologically barren. A fourth interval dominated by the micrinitic facies extends above the highest palynologically dated sample, 603B-26-4, 27-29 cm, to the top of the Plantagenet Formation (603B-22-4, 108-110 cm). Units KT4(CT) and KT5(CT) are modified by the fact that the terrigenous organic matter consists of the concentration of carbonized tracheids. The sedimentological origin of these particles is not clear, but they are ultimately derived from a terrestrial source and they do dominate their residues. However, they cannot be considered as typical tracheal facies as they do not always contain appreciable numbers of the larger spores.

The stratigraphic alternation of mostly terrigenous (tracheal and exinitic facies) and mostly pelagic (xenomorphic facies) units agrees, within the resolution of one-

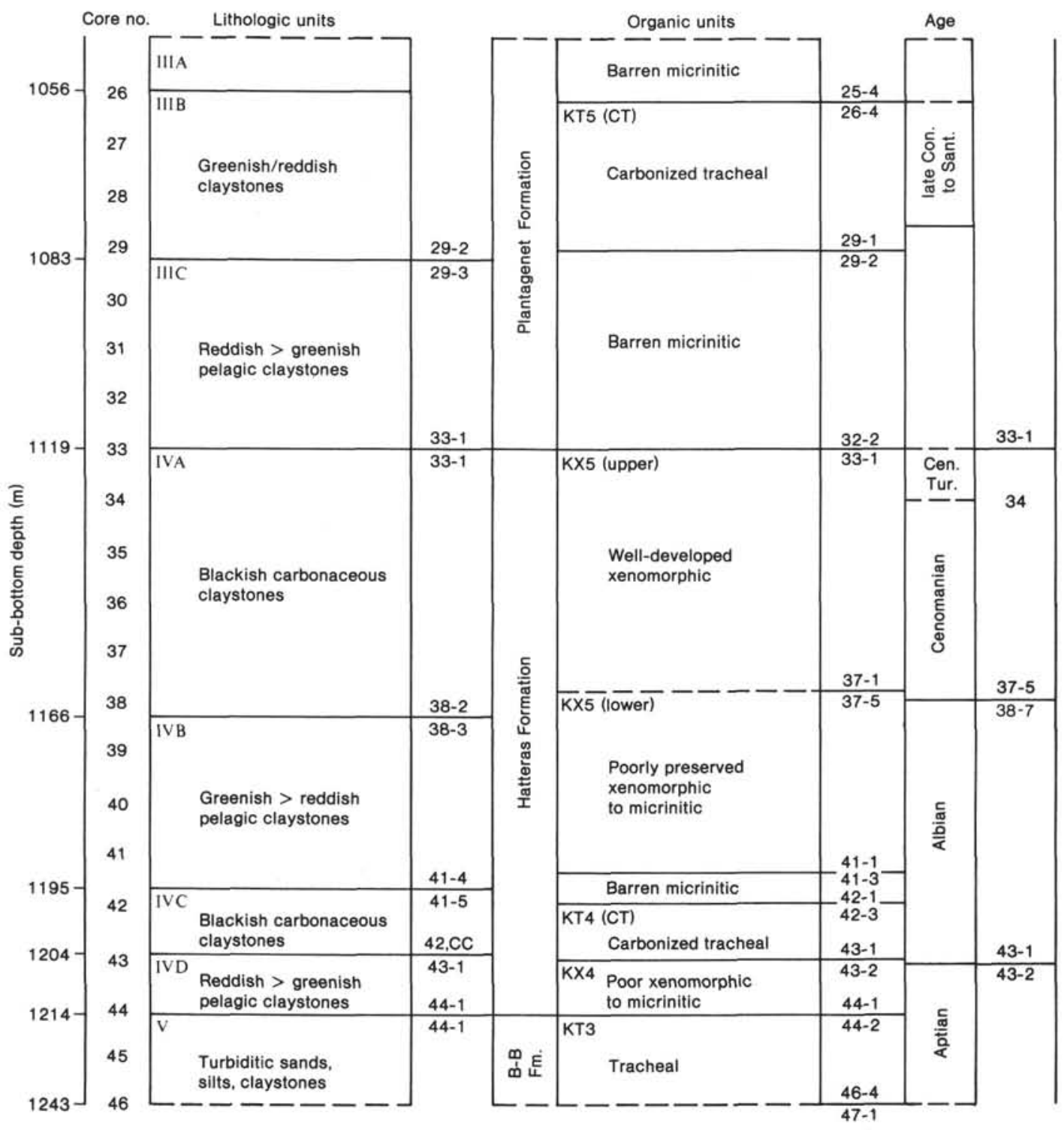

Figure 3. Comparison of lithologic units and organic units in the Aptian-Santonian interval in Hole 603B. Core and section numbers of unit boundaries noted on right-hand side of each column. 
half of a stage, with that of other sites that have been investigated in the North Atlantic Cretaceous (Habib, $1982 \mathrm{~b})$. Terrigenous units at Site 603 which correlate with other sites occur within the Valanginian (KT1), late Hauterivian-early Barremian (KT2), Aptian (KT3), and early? Albian (KT4 [CT]). A fifth terrigenous unit (KT5 [CT]) is distinguished for the first time, within the late Coniacian-Santonian interval in the Plantagenet Formation. Alternating units characterized by the xenomorphic facies occur within the late Berriasian-Valanginian (KX1), Hauterivian (KX2), Barremian (KX3), Aptian (KX4), and Albian-Cenomanian (KX5).

The best-developed terrigenous units (KT1-KT3) are distributed through the carbonate-rich Blake-Bahama Formation, in terrigenous claystones which are generally associated with turbiditic silts and sands (Site 603 chapter, this volume). The lower boundary of unit KT1 in section 603B-75-5 coincides, given the degree of resolution permitted by the sampling intervals, with the lowest occurrence of terrigenous claystone turbidites in Section 603B-76-1. Terrigenous organic intervals are also intermittently distributed in the poorly preserved xenomorphic units of Hauterivian (KX2) and Barremian (KX3) ages. The lowest occurrence of abundant siltstone and sandstone turbidites in Core 603B-67 is followed stratigraphically by the occurrence of unit KT2 in core 603B60 , in claystones of late Hauterivian age. It is within this unit that the terrigenous organic facies is best expressed at Site 603. In both samples from Core 603B-56 (early Barremian) the facies is exinitic, where palynomorphs reach a maximum in the investigated section of approximately $86,000 / \mathrm{g}$ approximately $93 \%$ being land-derived sporomorphs. Sample 603B-56-3, 81-83 cm contains numerous larger spores, megaspores, and sporangial tissue containing Converrucosisporites sp. It is a typical, poorly sorted assemblage of palynomorphs and tracheids which, like the Barremian exinitic facies at Site 398 , was rapidly deposited and buried in an ancient submarine fan environment. Unit KT3 is similar in its association with sandstone turbidites of Aptian age, although the organic facies is not so well developed. Nevertheless, numerous well-preserved tracheids occur with larger spores, although this latter group is not so well represented. In contrast to the terrigenous units and poorly preserved xenomorphic units in the predominantly terrigenous part of the Blake-Bahama Formation, the xenomorphic facies in unit $\mathrm{KX} 1$ is well developed in late Berriasian-Valanginian pelagic nannofossil limestones and chalks lacking any turbidites (Site 603 chapter, this volume).

Both the Hatteras and Plantagenet formations are characterized by variegated reddish brown to greenish gray noncalcareous pelagic claystones containing terrigenous silts and intervals of dark gray carbonaceous claystone. The organic units correspond closely with the major lithologies (Fig. 3). Based on the stratigraphic occurrence of refractory organic matter (as carbonized tracheids) in the background pelagic sediment, the carbonized tracheal facies of unit KT4(CT) in the Hatteras Formation is interpreted as the residue of rapidly sedimented terrigenous organic matter which subsequently suffered buried sediment oxidation during much slower sedimentation of pelagic clays below the carbonate compensation depth. The dark color of these claystones is due to the black color of the carbonized tracheids, which resulted from the arrested oxidation of woody tissue in a manner comparable to that which produces the black color of charcoaled wood. In the lower part of the Hatteras Formation, the residues of black claystones directly above unit KT4 (CT) are palynologically barren in black micrinite. The color of these claystones may have been produced in the same way.

The Hatteras Formation also contains major episodes of sedimentation of predominantly pelagic organic matter. In unit KX4 of Aptian age and in the lower part of unit KX5 of Albian age, the xenomorphic facies is poorly preserved and contains samples of palynologically barren micrinite in a background lithology of oxidized pelagic claystones (Fig. 3). The brownish color of the amorphous debris, in relatively small organic residues, is consistent with the diagenetic effects resulting from slower sedimentation in an oxidizing water column. In contrast, the upper part of unit KX5 contains a rich xenomorphic facies which correlates with marine-carbon-rich Cenomanian sapropels at other sites (Ryan and Cita, 1977). The widespread occurrence of rich pelagic organic matter requires an episode of high organic productivity of planktonic algae (and rapid sedimentation of zooplanktonic fecal pellets) in the Cenomanian North Atlantic.

In the western North Atlantic basin, the Plantagenet Formation is a relatively thin but widespread lithostratigraphic unit (Lancelot et al., 1972). The major lithology is variegated reddish, yellowish, and brownish noncalcareous claystone with intercalations of greenish claystone. According to Jansa et al. (1979), these pelagic red clays accumulated very slowly, in the order of 2 to $3 \mathrm{~m} /$ m.y. The predominant lithology is the same at Site 603, with Mn-stained laminae in some intervals suggesting very slow sedimentation (Site 603 chapter, this volume). However, at Site 603 it differs from all other sites at which it has been recovered by the presence of terrigenous silts and terrigenous organic matter (unit KT5 [CI]). The occurrence of these blackish terrigenous clays in a slowly sedimenting, oxidizing, background environment is presented as evidence that there were relatively short episodes of rapid sedimentation of terrigenous detritus, in which tracheal tissue was later carbonized by diagenetic oxidation.

In conclusion, the formation of carbonaceous clays at Site 603 was based to a large extent on the sedimentary supply and rate of burial of organic particles of various origins. Each sample contains at least some admixture of organic matter of terrestrial and of pelagic origins. However, each of these sources can be identified by the predominance of the particles which defines its organic facies. Where available, geochemical evidence has corroborated the origin of the organic facies.

Although these conclusions are based on investigation of the claystone lithology, there is also a general correspondence between the organic units defined by the predominant organic facies and the stratigraphy and sedimentology of the major lithologies. The stratigraphic alternation of the terrigenous and pelagic unit is pene- 
contemporaneous throughout the North Atlantic Cretaceous, except for the terrigenous event in the Plantagenet Formation, which is described for the first time. Hauterivian and Barremian pelagic events at Site 603 contain a larger admixture of land plant particles than elsewhere in the western North Atlantic, but this is consistent with the submarine fan environment in which each was being deposited.

If the occurrence of carbonaceous clays was controlled primarily by sedimentological parameters, then there is no need for there to have been paleoceanography of anoxic water masses. Rapid burial of terrigenous organic matter would turn the buried sediment environment anoxic; slower accumulation would result in a diagenetic environment in which only incompletely oxidized, refractory, organic matter would survive. The color in both examples could be the same. The blackish color in the first would result from the abundance of the organic residue. In the second, it could result from the color of the "charcoaled" tissue itself. The well-preserved pelagic episodes of late Berriasian-Valanginian and Cenomanian ages are the result of the rapid supply of amorphous debris in the form of zooplanktonic fecal pellets, independent of the rate of accumulation of mineral sediment. If the organic carbon content of the Cenomanian sapropel is higher, it may be because of its deposition below the carbonate compensation depth.

\section{SITE 605}

Drilling at Site 605 penetrated to a depth below seafloor of approximately $817 \mathrm{~m}$. The palynological dated interval is approximately $58 \mathrm{~m}$ thick, and extends from the stratigraphic level of Core 605-66 to the bottom of the recovered section in Core 605-71. Forminiferal and calcareous nannofossil evidence (Site 605 chapter, this volume) indicates that the Cretaceous/Paleogene boundary occurs within Section 605-66-1.

The general lithology of the interval consists of olive gray, moderately bioturbated, foraminifer-rich and calcareous-nannofossil-rich clayey limestone containing glauconite and terrigenous silt. A transitional lithological boundary occurs within Section 605-66-1: above it glauconite and terrigenous silt increase and forminifers correspondingly decrease in abundance. This boundary generally coincides with the paleontological boundary.

Eight samples from the interval were examined (Appendix A). All were found to be rich in dinocysts, including a number of species in Spiniferites and Areoligera. The dinoflagellate stratigraphy across the boundary at Site 605 is remarkably similar to that published by Hansen (1979) for the Maestrichtian/Danian boundary in Denmark. Two samples were examined from adjacent the Cretaceous/Paleogene boundary as predicted from the study of the other microfossils. Sample 605-66-1, 61-64 cm lies above this boundary, and contains Carpatella cornuta Grigorovich and Membranilarnacia tenella Morgenroth. Both of these are guide species for the early Danian. Sample 605-66-1, 78-81 cm lies below the predicted boundary, and contains Dinogymnium acuminatum and Palynodinium grallator Gocht. Both of these are guide species for the Late Cretaceous. Based on the stratigraphic distribution of these four species, the Cretaceous/Paleogene boundary can be placed with confidence between the two samples studied in Section 60566-1. The stratigraphic distribution of these and other species is illustrated in Figure 4. Pierceites pentagonum (May) n. comb. occurs in the lowest two samples studied (Appendix A). May (1980) described this species from the middle Maestrichtian Navesink Formation from the Atlantic Highlands in New Jersey.

\section{TAXONOMIC NOTES}

\section{Genus PIERCEITES new genus}

Type species. Pierceites schizocystis, new species.

Diagnosis. Proximate peridinioid dinoflagellate cysts, with one smoothly tapering apical horn and two unequally developed antapical horns. Wall layers closely appressed, without pericoels. Archeopyle 3I. Operculum compound, with three opercular pieces corresponding to plates of intercalary series; opercular pieces free; when they remain in place, each is always completely outlined by an archeopyle suture. Cyst tabulation, if present, is peridiniacean; it is expressed by sutural lines of dehiscence defining plate boundaries, and not by positive structures such as ridges, septa, or processes, or by patterns of ornamentation.

Remarks. Pierceites is distinguished from other peridinioid genera with the $3 \mathrm{I}$ archeopyle by its lack of pericoels underlying any area of the periphragm. Except for the archeopyle, it may lack any evidence of tabulation. However, when it is expressed, it is by sutural lines of dehiscence which define plate boundaries in the cyst. Both Trithyrodinium Drugg and Ginginodinium Cookson and Eisenack possess a 3I archeopyle, but are proximocavate. Also, in the latter genus, when there is evidence of tabulation it is expressed by positive features of the periphragm. Pareodinia Wiggins may also possess a 3I archeopyle, but does not possess antapical horns. Pierceites is named in memory of the stratigraphic palynologist, Richard L. Pierce.

\section{Pierceites schizocystis new species (Plate 6, Figs. 1-6)}

Holotype. Sample 603B-34-6, 15-17 cm. Plate 6, Fig. 1, $85 \times 61$ $\mu \mathrm{m}$. Repository at Queens College of the City University of New York.

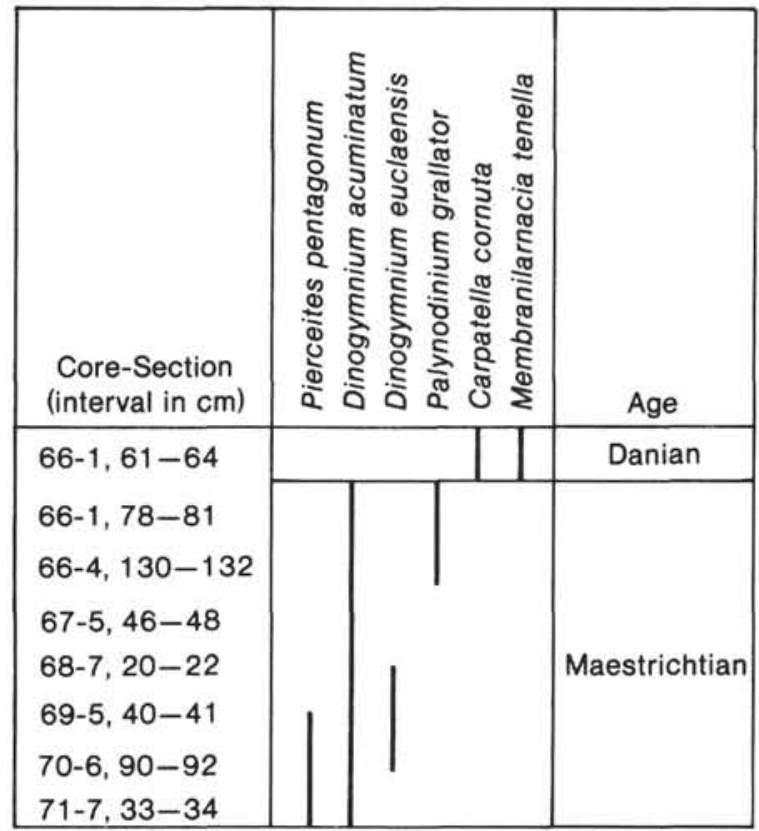

Figure 4. Stratigraphic range chart, showing stratigraphically important dinoflagellate species at Hole 605 . 
Description. Proximate autocysts with rounded peridinioid outline. Cyst wall thin, $-0.5 \mu \mathrm{m}$ thick. Evidence of pericoels lacking. Apical horn broadly based and tapers smoothly to a rounded apex. Antapical horns usually weakly developed and of unequal length; left horn longer, right horn reduced or occasionally undeveloped. Structural evidence of a cingulum lacking; its position is inferred in those cysts where the epicyst partially or completely splits from the hypocyst, or where precingular plates dehisce from hypocyst. Sulcus not evident. Except for the archeopyle, evidence of cyst tabulation is lacking in most specimens. However, in other specimens, the epicystal tabulation is expressed by sutural lines of dehiscence defining plate boundaries of the apical, intercalary, and percingular series and by the separation of individual plates, especially in the precingular series. Hypocystal tabulation not evident. Partial tabulation formula is peridiniacean: $4^{\prime}, 3 \mathrm{a}$, $7^{\prime \prime}$. Apical series distinguished by first apical plate $\left(1^{\prime}\right)$ which does not extend to the apex; sutural boundary of second apical $\left(2^{\prime}\right)$ and fourth apical $\left(4^{\prime}\right)$ plates in direct contact in ventral side of apical horn. Intercalary series typically peridiniacean; mid-dorsal second intercalary plate ( $2 a)$ attenuated, but with the $2 a / 3^{\prime}$ boundary not much shorter than the $2 \mathrm{a} / 4^{\prime \prime}$ ' boundary. Precingular plates may dehisce individually along cingular margin and from remainder of epicyst. Archeopyle formula 3I. Operculum compound, with each opercular piece corresponding to a plate of the intercalary series; opercular pieces generally separate, but may remain in place. Cyst surface evenly scabrate to finely granulate. Pustules are commonly scattered among granules, but may also be more densely distributed. Cyst length ranges from 70 to $85 \mu \mathrm{m}$; width from 49 to $62 \mu \mathrm{m}$. Apical horn ranges from 10 to $16 \mu \mathrm{m}$ in length; left antapical horn from 5 to $10 \mu \mathrm{m}$.

Remarks. Pierceites schizocystis is distinguished by its rounded peridinioid outline, surface ornamentation, inclusion of specimens which possess an epicystal tabulation outlined by suturally deshicing boundaries, and lack of sulcus and cingulum. The species is named after the common splitting of the epicyst. Evitt (1967, pl. 3, fig. 16) illustrated a specimen he labelled Forma Q, from the Cretaceous of South Dakota. It is referable to the genus Pierceites, and is close to P. schizocystis. It differs by its possession of a distinct cingulum.

\section{Pierceites pentagonum (May) new combination}

(Plate 6, Figs. 7-9) 14.

Trithyrodinium pentagonum May, 1980 , p. $87-88$, pl. 10, figs. $13-$

Remarks. This species is similar to $P$. schizocystis, but is distinguished by its pentagonal outline, defined by near-rectilinear margins in dorsoventral compression, and by its possession of cingulum. Cyst tabulation in this species is expressed by sutural lines (archeopyle sutures) which outline each of three opercular pieces which may remain in place. $P$. pentagonum occurs in Samples 605-71-7, 33-34 cm and $605-70-6,90-92 \mathrm{~cm}$ at Site 605 . Included are specimens in which the opercular pieces have been removed.

\section{Genus DIACANTHUM Habib, 1972, emended}

Type species. Diacanthum hollisteri Habib, 1972, emended.

Emended diagnosis. Spheroidal proximate autocysts compressed to a subcircular outline. Cyst tabulation sexiform gonyaulacoid with Ltype ventral organization; tabulation indicated by narrow septal boundaries. Cyst wall perforate, and with intratabular spines which may form spinate ridges. Archeopyle precingular $2 \mathrm{P}_{3}{ }^{\prime \prime-} 4^{\prime \prime}$; it may be variable in the precingular series, as in the type species, but must include examples which involve the third and fourth precingular plates, either

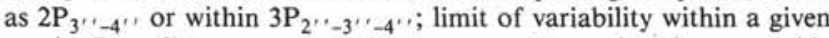

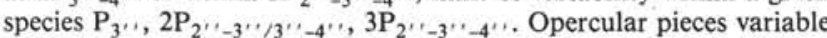
in number; they may remain partially attached (adnate or adherent) to the cyst, or detached; one or more detached pieces may remain closely associated with the cyst. Apical horn may be present or absent.

Remarks. The concept of Diacanthum is emended to accommodate the variability of archeopyle development observed in the type species. The perforate wall structure is also considered to be diagnostic. It is distinguished from perforate species in Occisucysta Gitmez, 1969 and Cribroperidinium Neale and Sargeant, 1962, emended Helenes, 1984, both of which have sexiform gonyaulacoid tabulation and L-type ventral organization, by the nature of the archeopyle.
Diacanthum hollisteri

(Figure 5; Plate 1, Figs. 7-8; Plate 2, Figs. 1-2, 4-5, 7-8; Plate 3, Figs. 1-4; Plate 8, Figs. 1-6; Plate 9, Figs. 1-4)

Emended description. Relatively large, spheroidal, proximate cysts which, when compressed, have an oval, subcircular, or elliptical outline; because of almost equidimensional shape, compressions may variy from lateral to dorsoventral to apical/antapical; outline largely controlled by arcuate lenticular compression folds which are concentrated near the periphery. Wall thin, less than $0.5 \mu \mathrm{m}$ thick; it is densely perforate, and at least some of the perforations penetrate it completely. Discrete, short apical horn may be present, or there may instead be a rounded apical protuberance formed by the confluence of plate boundaries. Cingulum thin, and displaced approximately one cingulum-width adjacent the sulcus. Sulcus confined largely to hypocyst; hypocystal part characterized by medial linear splitting of the wall layer which extends from near the posterior end of the sulcus, from the posterior sulcal plate, to the approximation position of the intersection of the cingulum and the sulcus. Cyst tabulation expressed by relatively high, perforate to vertically striate, septa which define plate boundaries. Relatively short, blunt-tipped, conical spines cluster in the intratabular area; within a given plate, they may be joined at the base to form an intratabular ridge adjacent a septum; intratabular ridge may be straight or curved. Striations radiate from the base of each spine, giving the appearance on the surface of an uneven mosaic of spines, striations, and perforations which mask the thinness of the cyst wall itself. Cyst tabulation sexiform gonyaulacoid with L-type ventral organization; formula pr, $4^{\prime}, \mathrm{Oa}, 6^{\prime \prime} \mathrm{Xc}, 6^{\prime \prime \prime}, 1 \mathrm{p}, 1^{\prime \prime \prime}{ }^{\prime \prime}, 4-5 \mathrm{~s}$. Epicystal tabulation characterized by a narrow sixth precingular plate $\left(6^{\prime \prime}\right)$ which is subparallel to the adjacent, more-or-less straight sulcus, a correspondingly wide fifth precingular plate $\left(5^{\prime \prime}\right)$ and a narrower but higher, attenuated trapezoidal to almost triangular first precingular plate $\left(1^{\prime \prime}\right)$. The second $\left(2^{\prime \prime}\right)$ and fourth $\left(4^{\prime \prime}\right)$ precingular plates are trapezoidal, and lie on either side of the mid-dorsal, pentagonal, third ( $\left.3^{\prime \prime}\right)$ precingular plate. Plate $2^{\prime \prime}$ is almost rectangular, and is larger than the almost square (quadrate) plate $4^{\prime \prime}$. The apical series consists of a narrow, rectangular to slightly convexly bowed, first apical plate ( $\left.1^{\prime}\right)$, a hexagonal second apical plate $\left(2^{\prime}\right)$, and a pentagonal fourth apical plate $\left(4^{\prime}\right)$, the three of which have a common juncture at the apex. The apical horn, when discrete, arises from this juncture and may be flat-topped in the form of a small, pentagonal, preapical plate (pr.). In some cysts, the pr. plate is divided by a raised partition. The third apical plate $\left(3^{\prime}\right)$ is pentagonal; it is displaced to the right and dorsal of the apex along the length of the common boundary between plates $2^{\prime}$ and $4^{\prime}$. The hypocystal tabulation is characterized by a small first postcingular plate $\left(1^{\prime}\right)$ which is always smaller than the first posterior intercalary plate (lp). The third plate $\left(3^{\prime \prime \prime}\right)$ curves under the lp and second postcingular $\left(2^{\prime \prime \prime}\right)$ plates, and contacts the antapical plate without contacting the sulcus. The fourth postcingular plate $\left(4^{\prime \prime}{ }^{\prime \prime}\right)$ is relatively small and rectangular. The fifth postcingular plate $\left(5^{\prime \prime \prime}\right)$ is large and curves under a small, semicircular, sixth postcingular plate $\left(6^{\prime \prime \prime}\right)$. The single antapical plate $\left(1^{\prime \prime \prime}\right)$ is indented on the ventral side by contact with the sulcus; the right side of plate $1^{\prime \prime}$ ' ' is longer than its left side. Sulcal tabulation formula ps, ls, rs, ras, as. Commonly, the right anterior sulcal (ras) is absent, and the left sulcal (ls) and right sulcal (rs) plates lie on either side of the medial split. The posterior sulcal (ps) is rounded at its posterior end. The anterior sulcal (as) is narrow. Archeopyle is variable, in the loss of one, two or three precingular plates; formula $\mathrm{P}_{3^{\prime \prime}}$, or $2 \mathrm{P}_{2^{\prime \prime}-3^{\prime \prime}}$, or $2 \mathrm{P}_{3^{\prime \prime}-4^{\prime \prime}}$, or $3 \mathrm{P}_{2^{\prime \prime}-3^{\prime \prime}-}$ 4'.. Most frequently, the second and third precingular plates form the archeopyle; less frequently, it corresponds to the third and fourth precingular plates or to the second, third, and fourth precingular plates; rarely, it is formed by the opening of the third precingular plate alone. In most cysts, the operculum is free; most frequently it is adherent to the cyst along the boundary with the cingulum or detached from the cyst but remaining closely associated to it. There may be one or two opercular pieces in those cysts with the $2 \mathrm{P}$ archeopyle. Size of the cysts varies from 75 to $105 \mu \mathrm{m}$ in maximum dimensions.

Remarks. The emended description of Diacanthum hollisteri is based on the restudy of a large number of specimens from Sites 105 (Habib, 1972), 534 (Habib and Drugg, 1983) and 603, as well as from the European Tethyan stratotype and parastratotype sections of the Berriasian and Valanginian stages. Restudy of type material of D. hol- 

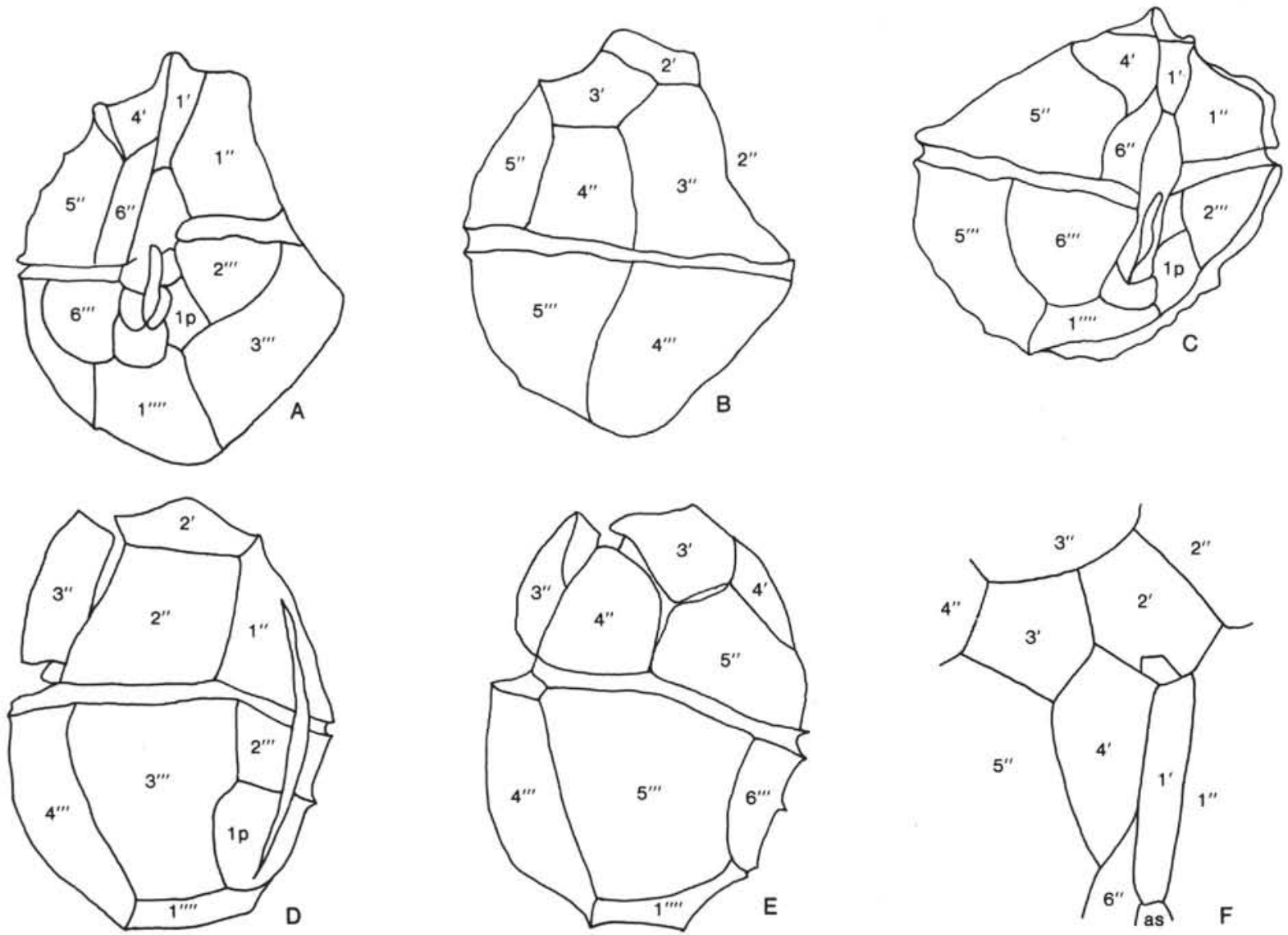

Figure 5. Diacanthum hollisteri Habib presented in a schematic Kofoid-style tabulation of specimens illustrated in Plates 1 and 2. A, B. Tabulation of specimen illustrated in Plate 1, Fig. 7. Archeopyle $2 \mathrm{P}_{2}{ }^{\prime \prime}-3^{\prime \prime}$. Medial splitting of the sulcus. C. Ventral surface tabulation of specimen illustrated in Plate 2, Fig. 4. D, E. Tabulation of specimen illustrated in Plate 2, Fig. 8. Archeopyle $2 \mathrm{P}_{3^{\prime \prime}}-^{\prime \prime}$. Quadrate fourth precingular plate $\left(4^{\prime \prime}\right)$ remains attached at the cingulum. F. Tabulation of plates near apex, after specimen illustrated in Plate 2, Fig. 2. Preapical plate formed at juncture of first $\left(1^{\prime}\right)$, second $\left(2^{\prime}\right)$ and fourth $\left(4^{\prime}\right)$ apical plates. Third apical plate $\left(3^{\prime}\right)$ offset from apex. $1 \mathrm{p}$ - first posterior intercalary plate; as - anterior sulcal.

listeri from Site 100 (Sample 100-1,CC; Habib, 1972) was not successful, because of the poor residue that was recovered.

The definition of $D$. hollisteri is revised to disclose details of cyst tabulation, variability of the archeopyle formula, close association and even adherence of the operculum to the cyst in many specimens in a given assemblage, and variation in the number of opercular pieces. The species is distinguished further by its rotund appearance in those compressed specimens that are largely devoid of compression folds, and by the medial linear splitting of the sulcus which can be detected in appropriately oriented, well-preserved, specimens.

The morphology of $D$. hollisteri is similar to that of Occisucysta evittii (Dodekova) Gitmez and to species of Cribroperidinium such as C. conjunctum (Eisenack and Cookson) Helenes. In O. evittii, C. conjunctum, and $D$. hollisteri hypocystal plate $5^{\prime \prime} '$ is large and epicystal $5^{\prime \prime}$ is wide, especially when compared with epicystal $6^{\prime \prime}$ '. Also epicystal $6^{\prime \prime}$ is intercalated between apical plates $1^{\prime}$ and $4^{\prime}$ in the three species. In addition, although both epicystal plate $2^{\prime \prime}$ and $4^{\prime \prime}$ are trapezoidal, the former appears always to be larger than the latter. The species are similar also with respect to the L-type ventral tabulation of the cyst, sexiform organization of hypocystal tabulation, and presence of low-lying, spinate, intratabular ridges. $D$. hollisteri is also similar to Diacanthum filapicatum (Gocht) Stover and Evitt. The species apparently share the basic cribroperidinioid plate geometry given above. In addition, both species are perforate and possess intratabular spines (although $D$. filapicatum apparently does not possess intratabular ridges), and in both species, for example, Gocht, 1970, pl. 27, fig. 2, there are examples of a medial splitting of the sulcus which extends from the posterior sulcal plate to the level of the cingulum. However, $D$. filapicatum differs from $D$. hollisteri by the presence of two small plates intercalated near the precingular margins of apical plates $2^{\prime}$ and $3^{\prime}$ and by the apparently common juncture of all apical plates at the apex (Gocht, 1970, p. 134, fig. 4).

The single feature which distinguishes $D$. hollisteri collectively from the three species with which it is compared is the variability of the excystment apparatus. The extent of archeopyle variability is from $\mathrm{P}_{3^{\prime \prime}}$,

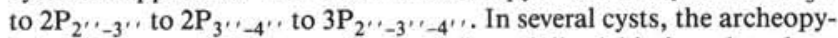
le is $2 \mathrm{P}_{2}^{\prime \prime}-3$ ' with sutures (not septa) partially dehiscing also along the adjacent fourth precingular plate. The operculum may remain adherent at the cingulum, or laterally against adjacent percingular plates. Opercula which are detached from the cyst but remain close to the archeopyle are considered to have been originally adherent, but became detached at some stage during sample preparation. Otherwise it is difficult to envision how an operculum can be completely disconnected from the cyst but remain so closely associated to it through the processes of excystment and/or sedimentation. The operculum may consist of one or two pieces.

In Cribroperidinium, the archeopyle is always $\mathrm{P}_{3}$, and the operculum is free, although there are species in which the operculum is adherent (Helenes, 1984). In Occisucysta, the archeopyle is $2 \mathrm{P}_{2^{\prime \prime}}{ }_{-3}{ }^{\prime \prime} \cdot$ According to the description of $O$. evittii, given by Dodekova, 1969, all specimens that were examined contained the fully developed archeopyle. In specimens that were attributed to $O$. evittii by Below (1982), the operculum is free and consists of two opercular pieces. Below (1982) also illustrated a specimen with the $\mathrm{P}_{2^{\prime}}$, archeopyle. In $D$. filapicatum, the archeopyle is $2 \mathrm{P}_{3}{ }^{\prime \prime}-4^{\prime \prime}$. Gocht (1970) illustrated a specimen he designated the holotype with the $\mathrm{P}_{3}$." plate completely detached and the $\mathrm{P}_{4}$, plate partially detached.

There are a number of species in sections of Middle Jurassic to Early Cretaceous age which resemble $D$. hollisteri in the possession of Cribroperidinium-like tabulation, spinate intratabular ridges, and per- 
forate cyst wall. Detailed examination which takes into account the variability which may occur in fossil populations may reveal the taxonomic and phylogenetic relationships of these taxa. Nevertheless, $D$. hollisteri is a valuable guide species (and is stratigraphically important) in the Berriasian-Valanginian Tethyan western North Atlantic (and adjacent Gulf of Mexico; Riley and Fenton, 1984) and Tethyan submediterranean European stratotype and parastratotype sections of the Berriasian and the Valanginian. It is a species which is apparently absent or rare in the Boreal province. This species should not be confused with the species from the Early Cretaceous of Morocco which Below (1982) considered to be the senior synonym of $D$. hollisteri.

\section{ACKNOWLEDGMENTS}

We are grateful for the anonymous critical reviews of the manuscript. We are also grateful to Lucy E. Edwards (U.S. Geological Survey, Reston), James G. Ogg (Scripps Institution of Oceanography), Peter Roth (University of Utah), and Phillip Meyers (University of Michigan), who critically reviewed the manuscript for us. Paula Weiss assisted in the collection of the samples and Robert van Pelt prepared them for study. Lina McClain typed the manuscript. Howard Craig prepared the diagrams. Martha Nell Mixon prepared the scanning electron micrographs.

We are grateful to Chevron Oil Field Research Company for providing time and facilities for this study. This study was supported by a grant from the National Science Foundation, OCE-8303695.

\section{REFERENCES}

Below, R., 1982. Dinoflagellate cysts from Valanginian to lower Hauterivian sections near Ait Hamouch, Morocco. Rev. Espan. Micropaleontol., 14:23-52.

Bujak, J. P., and Williams, G. L., 1979. Dinoflagellate diversity through time. Mar. Micropaleontol., 4:1-12.

Davey, R. J., 1978. Marine Cretaceous palynology of Site 361, DSDP Leg 40, off southwestern Africa. In Bolli, H. M., Ryan, W. B. F., et al., Init. Repts. DSDP, 40: Washington (U.S. Govt. Printing Office), 883-913.

DeRenéville, P., and Raynaud, J.-P., 1981. Palynologie du stratotype du Barrémien. Soc. Nat. Elf-Aquitaine, 5:1-29.

Deroo, G., Graciansky, P. C. de, Habib, D., and Herbin, J.-P., 1978. L'origine de la matiere organique dans les sédiments crétacés du Site I.P.O.D. 398 (haut-fond de Vigo): corrélations entre les donnés de la sédimentologie, de la géochimie organique et de la palynologie. Bull. Soc. Geol. Fr., 20:465-469.

Dodekova, L., 1969. Dinoflagellés et acritarches du Tithonique aux environs de Pleven, Bulgarie centrale du nord. Bulgarian Acad. Sci., Bull. Geol. Inst., Ser. Paleontol., 18:13-29.

Evitt, W. R., 1967. Dinoflagellate studies, II. The archeopyle. Standford Univ. Publ., 10:1-83.

Gocht, H., 1970. Dinoflagellaten-zystem aus dem Bathonium des Erdölfeldes Aldorf (NW Deutschland). Paleontographica, B, 129-165.

Habib, D., 1972. Dinoflagellate stratigraphy, Leg 11, Deep Sea Drilling Project. In Hollister, C. D., Ewing, J. I., et al., Init. Repts. $D S D P, 11$ : Washington ('TS. Govt. Printing Office), 367-425. 1977. Comparison of Lower and Middle Cretaceous palynostratigraphic zonations in the western North Atlantic. In Swain, F. M. (Ed.), Stratigraphic Micropaleontology of Atlantic Basin and Borderlands: New York (Elsevier Publishing Company), 6:341367.

1978. Palynostratigraphy of the Lower Cretaceous section at DSDP Site 391, Blake-Bahama Basin, and its correlation in the North Atlantic. In Benson, W. E., Sheridan, R. E., et al., Init. Repts. DSDP, 44: Washington (U.S. Govt. Printing Office), 887897.

1979a. Palynostratigraphy of Cretaceous sediments from Site 387, western Bermuda Rise. In Tucholke, B. E., Vogt, P. R., et al., Init. Repts. DSDP, 43: Washington (U.S. Govt. Printing Office), 585-589.

1979b. Sedimentology of palynomorphs and palynodebris in Cretaceous carbonaceous facies. In Sibuet, J.-C., Ryan, W. B. F., et al., Init. Repts. DSDP, 47, Pt. 2: Washington (U.S. Govt. Printing Office), 451-465.

1982a. Sedimentary supply origin of Cretaceous black shales. In Schlanger, S. O., and Cita, M. B. (Eds.), Nature and
Origin of Cretaceous Carbon-rich Facies: New York (Academic Press), pp. 113-127.

1982b. Sedimentation of black clay organic facies in a Mesozoic oxic North Atlantic. Third N. Am. Paleontol. Conv., Proc., 1:217-220.

, 1983. Sedimentation-rate-dependent distribution of organic matter in the North Atlantic Jurassic-Cretaceous. In Sheridan, R. E., Gradstein, F. M., et al., Init. Repts. DSDP, 76: Washington (U.S. Govt. Printing Office) 781-794.

Habib, D., and Drugg, W. S., 1983. Dinoflagellate age of Middle Jurassic-Early Cretaceous sediments in the Blake-Bahama Basin, In Sheridan, R. E., Gradstein, F. M., et al., Init. Repts. DSDP, 76: Washington (U.S. Govt. Printing Office), 623-638.

Habib, D., and Warren, J. S., 1973. Dinoflagellates near the Cretaceous-Jurassic boundary. Nature, 241:217-218.

Hansen, J. M., 1979. A new dinoflagellate zone at the Maastrichtian/ Danian boundary in Denmark. Geol. Surv. Denmark, Yearbook 1978, pp. 131-140.

Helenes, J., 1984. Morphological analysis of Mesozoic-Cenozoic Cribroperidinium (Dinophyceae), and taxonomic implications. Palynology, 8:107-137.

Jansa, L., Enos, P., Tucholke, B. E., Gradstein, F. M., and Sheridan, R. E., 1979. Mesozoic-Cenozoic sedimentary formations of the North Atlantic Basin, western North Atlantic. In Talwani, M., Hay, W. W., and Ryan, W. B. F. (Eds.), Deep Drilling Results in the Atlantic Ocean: Continental Margins and Paleoenvironment. Am. Geophys. Un., Maurice Ewing Ser., 3:1-57.

Lancelot, Y., Hathaway, J. C., and Hollister, C. D., 1972. Lithology of sediments from the western North Atlantic, Leg XI, Deep Sea Drilling Project. In Hollister, C. D., Ewing, J. I., et al., Init. Repts. DSDP, 11: Washington (U.S. Govt. Printing Office), 901950.

May, F. E., 1980. Dinoflagellate cysts of the Gymnodiniaceae, Peridiniaceae, and Gonyaulacaceae from the Upper Cretaceous Nonmouth Group, Atlantic Highlands, New Jersey. Palaeontographi$c a, B, 172: 10-116$.

Morgan, R., 1980. Palynostratigraphy of the Australian Early and Middle Cretaceous. Mem. Geol. Surv. New South Wales, Palaeontology No. 18.

Porter, K. G., and Robbins, E. I., 1981. Zooplankton fecal pellets link fossil fuel and phosphate deposits. Science, 212:931-933.

Riley, L. A., and Fenton, J. P. G., 1984. Palynostratigraphy of the Berriasian to Cenomanian sequence at DSDP Site 535, Leg 77, southeastern Gulf of Mexico. In Buffler, R. T., Schlanger, W., et al., Init. Repts. DSDP, 77: Washington (U.S. Govt. Printing Office), 675-690.

Robaszynski, F., Alcaydé, G., Amédro, F., Badillet, G., Damotte, R., Foucher, J.-C., Jardiné, S., Legoux, O., Manivit, H., Monciardini, C., and Sornay, J., 1982. Le Turonian de la région-type: Saumurois et Touraine. Stratigraphie, biozonations sédimentologie. Soc. Nat. Elf.-Aquitaine, 6:119-225.

Roth, P. H., and Thierstein, H., 1972. Calcareous nannoplankton: Leg 14 of the Deep Sea Drilling Project In Hayes, D. E., Pimm, A. C., et al., Init. Repts. DSDP, 14: Washington (U.S. Govt. Printing Office), 421 486.

Ryan, W. B. F., and Cita, M. B., 1977. Ignorance concerning episodes of ocean-wide stagnation. Mar. Geol., 23:197-215.

Sheridan, R. E., Gradstein, F. M., et al., 1983. Init. Repts. DSDP, 76: Washington (U.S. Govt. Printing Office).

von Rad, U., Ryan, W. B. F., et al., 1979. Init. Repts. DSDP, 47, Pt. 1: Washington (U.S. Govt. Printing Office).

Williams, G. L., 1975. Dinoflagellate and spore stratigraphy of the Mesozoic-Cenozoic, offshore eastern Canada. Geol. Surv. Can. Pap., 74 30:107-161.

Wiseman, J. F., and Williams, A. J., 1974. Palynological investigation of samples from Sites 259, 261, and 263, Leg 27. In Robinson, P. T., Bolli, H. M., et al., Init. Repts. DSDP, 27: Washington (U.S. Govt. Printing Office), 915-924.

Wolfe, J. A., 1976. Stratigraphic Distribution of Some Pollen Types from the Campanian and Lower Maestrichtian Rocks (Upper Cretaceous) of the Middle Atlantic States. U.S. Geol. Surv. Prof. Paper, 997.

Date of Initial Receipt: 6 February 1985

Date of Acceptance: 24 September 1985 
APPENDIX A

Samples Studied from Holes 603B and 605 .

Core-Section
(interval in cm)

Hole 603B

-22-4, 108-110

*22-5, 4-6

*23-2, 72-74

-24-2, 45-47

*25-4, 44-46

26-4, 27-29

*27-1, 80-82

$28-4,96-98$

29-1, 65-67

*29-2, 45-47

*30-5, 3-5

$* 31-5,5-7$

*32-2, 71-73

$33-1,80-82$

$33-3,122-124$

$34-1,70-72$

$34-5,45-47$

34-6, $15-17$

$35-2,10-12$

$35-4,55-57$

36-1, 105-107

36-3, 53-55

$37-1,34-36$

$37-5,68-70$

$38-1,37-39$

$38-1,35-37$

$38-5,54-56$

$39-1,20-22$

$39-2,50-52$

$39-5,57-59$

$40-1,12-14$

$40-2,38-40$

40-3, 33-35

$40-5,10-12$

*40-6, 27-29

41-1, 17-19

*41-3, 46-48

*41-4, 56-58

*41-5, 3-5

*42-1, 20-22

$42-3,27-29$

$42-6,37-39$

$43-1,608 \mathrm{~cm}$

*43-2, 22-24

*43-3, 134-136

43-4, 63-65

*43-5, 5-7

43-6, 22-24

44-1, 43-45

44-2, 50-52

44-4, 50-52

45-1, 98-100

$46-2,143-145$

$46-4,30-32$

$47-1,80-82$

48- $1,58-60$

48-2, 29-31

$49-1,120-122$

49-2, 40-42

$49-3,40-42$

49-5, 43-45

$50-1,58-60$

$51-7,25-27$

$52-7,38-40$

53-6, 35-37

54-5, 76-78

$55-5,12-14$

$56-2,86-88$

56-3, 81-83

$57-6,27-29$

$58-6,65-67$

59-5, 103-105

$60-4,16-18$

$61-6,69-71$
Poor xenomorphic

Micrinitic

Micrinitic

Micrinitic

Micrinitic

Carbonized tracheal

Poor xenomorphic

Carbonized tracheal

Carbonized tracheal

Micrinitic

Micrinitic

Micrinitic

Micrinitic

Xenomorphic

Xenomorphic

Xenomorphic

Xenomorphic

Xenomorphic

Xenomorphic

Xenomorphic

Xenomorphic

Xenomorphic

Xenomorphic

Poor xenomorphic

Micrinitic

Poor xenomorphic

Poor xenomorphic

Poor xenomorphic

Micrinitic

Poor xenomorphic

Poor xenomorphic

Micrinitic

Poor xenomorphic

Poor xenomorphic

Micrinitic

Poor xenomorphic

Micrinitic

Micrinitic

Micrinitic

Micrinitic

Carbonized tracheal

Carbonized tracheal

Carbonized tracheal

Micrinitic

Micrinitic

Micrinitic

Poor xenomorphic

Micrinitic

Poor xenomorphic

Tracheal

Poor xenomorphic

Tracheal

Tracheal

Tracheal

Micrinitic

Carbonized tracheids

Micrinitic

Micrinitic

Micrinitic

Carbonized tracheids

Poor xenomorphic

Poor xenomorphic

Poor xenomorphic

Poor xenomorphic

Tracheal

Poor xenomorphic

Exinitic

Exinitic

Tracheal

Poor xenomorphic

Tracheal

Poor xenomorphic

Poor xenomorphic
Poor xenomorphic
APPENDIX A (continued).

\begin{tabular}{l}
\hline $\begin{array}{c}\text { Core-Section } \\
\text { (interval in cm) }\end{array}$ \\
\hline
\end{tabular}

Hole 603B (Cont.)

$\begin{array}{ll}\text { 62-5, 60-62 } & \text { Poor xenomorphic } \\ 63-6,74-76 & \text { Tracheal } \\ 64-5,73-75 & \text { Tracheal } \\ 65-6,26-28 & \text { Tracheal } \\ 65-6,26-28 & \text { Poor xenomorphic } \\ 66-6,10-12 & \text { Poor xenomorphic } \\ 67-6,24-26 & \text { Poor xenomorphic } \\ 68-6,22-24 & \text { Poor xenomorphic } \\ 69-7,22-24 & \text { Micrinitic } \\ 70-6,8-10 & \text { Tracheal } \\ 71-6,3-5 & \text { Tracheal } \\ 72, C C & \text { Xenomorphic } \\ 73-5,5-7 & \text { Tracheal } \\ 74-7,4-6 & \text { Tracheal } \\ 75-5,50-52 & \text { Tracheal } \\ 76-5,19-21 & \text { Xenomorphic } \\ 77-7,13-15 & \text { Xenomorphic } \\ 78-4,33-35 & \text { Xenomorphic } \\ 79-7,0-2 & \text { Xenomorphic } \\ 80-1,20-22 & \text { Xenomorphic } \\ 80-6,17-19 & \text { Xenomorphic } \\ 81-1,19-21 & \text { Xenomorphic } \\ 81-3,49-51 & \text { Xenomorphic } \\ 81-6,9-11 & \text { Poor xenomorphic } \\ 82-1,117-119 & \text { Xenomorphic } \\ 82-2,101-103 & \text { Xenomorphic } \\ 82-3,53-55 & \text { Xenomorphic } \\ 84-4,15-17 & \text { Xenomorphic } \\ 82-5,51-53 & \text { Xenomorphic } \\ & \end{array}$

Hole 605

66-1, 61-64

$66-1,78-8$

$66-4,130-132$

67-5, 46-48

68-7, 20-22

69-5, 40-41

70-6, 90-92

71-7, 33-39

* Sample barren of palynomorphs.

\section{APPENDIX B}

Characteristics of Organic-Stratigraphic Units at Site 603 (Hole 603B)

1. KX1: Samples $603 \mathrm{~B}-82-5,51-53 \mathrm{~cm}$ to $603 \mathrm{~B}-76-5,19-21 \mathrm{~cm}$. Xenomorphic facies in all samples. Dinoflagellate species predominate, but classopollid-bisaccate pollen may outnumber dinocysts. Amorphous debris and fecal pelets are well preserved in most samples.

2. KT1: Samples 603B-75-5, 50-52 cm to 603B-73-5, 5-7 cm. Tracheal facies in all samples. Well-preserved tracheids are numerous, and larger spores range from $2500 / \mathrm{g}$ to $7000 / \mathrm{g}$. Classopollidbisaccate pollen predominate.

3. KX2: Samples $603 \mathrm{~B}-72, \mathrm{CC}$ to $603 \mathrm{~B}-60-4,16-18 \mathrm{~cm}$. Xenomorphic facies in most samples. However, the tracheal facies occurs in Samples 603B-71-6, 3-5 cm, 603B-70-6, 8-10 cm, 603B-64-5, $73-75 \mathrm{~cm}$, and 603B-63-6, 74-76 cm. Otherwise, the xenomorphic facies is poorly preserved, on the basis of the brownish color or amorphous debris and the admixture of micrinite. Palynomorphs are generally poorly preserved, and are dominated by classopollid-bisaccate pollen grains. Amorphous debris in fecal pellets also proorly preserved.

4. KT2: $\quad$ Samples 603-B-59-5, $103-105 \mathrm{~cm}$ to $603 \mathrm{~B}-54-5,76-78 \mathrm{~cm}$. Tracheal facies in all samples except for 603B-58-6, 65-67 cm and $603 \mathrm{~B}-55-5,12-14 \mathrm{~cm}$, which contain the poorly preserved xenomorphic facies, and 603B-56-3, 81-83 cm and 603B-56-2, 


\section{APPENDIX B (continued).}

$86-88 \mathrm{~cm}$, which contain the exinitic facies. Larger spores become most numerous in this unit, and range from $2500 / \mathrm{g}$ to a maximum in the investigated section of $9000 / \mathrm{g}$ in $603 \mathrm{~B}-56-3$, $81-83 \mathrm{~cm}$. Classopollid-bisaccate pollen are still predominant, but are reduced to approximately $56 \%$ in the exinitic samples.

5. KX3: Samples $603 \mathrm{~B}-53-6,35-37 \mathrm{~cm}$ to $603 \mathrm{~B}-49-5,43-45 \mathrm{~cm}$. Xenomorphic facies. The residues of most samples are sparse and contain the poorly preserved xenomorphic facies. Although the residues consist mostly of amorphous debris, tracheids do accur.

6.

Samples $603 \mathrm{~B}-49-3,40-42 \mathrm{~cm}$ to $603 \mathrm{~B}-47-1,80-82 \mathrm{~cm}$. Micrinitic to carbonized tracheal. The facies in this unit is largely fine-gained micrinitic. Micrinite is the most abundant constituent in the samples. Palynomorphs are few and poorly preserved. Carbonized tracheids are concentrated in samples $603 \mathrm{~B}-49-3,40-42 \mathrm{~cm}$, and 603B-48-1, 58-60 cm.

7. KT3: Samples 603B-46-4, 30-32 cm to 603B-44-2, 50-52 cm. Tracheal facies, in all samples except 603B-44-4, 50-52, which is xenomorphic. This unit is characterized by very large amounts of well-preserved tracheids admixed with lesser amounts of carbonized tracheids. Many of the larger spores occurring in unit KT2 are present. The larger spores reach a maximum of $3000 / \mathrm{g}$ in Sample 603B-45-1, 98-100 cm.

8. KX4: Samples $603 \mathrm{~B}-44-1,43-45 \mathrm{~cm}$ to $603 \mathrm{~B}-43-2, \mathrm{~cm}$. Poorly preserved xenomorphic facies. The residue is sparse in all of the samples. Palynomorphs are very few, and consist mainly of dinocysts and classopollid-bisaccate pollen. Several samples contain the micrinitic facies, and are barren of palynomorphs.

9. KT4 (CT): Samples $603 \mathrm{~B}-43-1,6-8 \mathrm{~cm}$ to $603 \mathrm{~B}-42-3,27-29 \mathrm{~cm}$. This unit is characterized by an abundance of carbonized tracheids and
APPENDIX B (continued).

fewer well-preserved tracheids. The unit is considered to be tracheal, but does not possess many larger spores.

10. Samples 603B-42-1, 20-22 cm to 603B-41-3, 46-48 cm are barren of palynomorphs in a homogeneous micrinitic facies.

11. KX5: Samples 603B-41-1, 17-19 cm to 603B-33-1, 80-82 cm. Xenomorphic facies. However, there is a sharp division in the development of this facies. The lower part, from Samples 603B-41$1,17-19 \mathrm{~cm}$ to $603 \mathrm{~B}-37-5,68-70 \mathrm{~cm}$, is typically represented by a sparse residue consisting of poorly preserved amorphous debris and few palynomorphs dominated by dinocysts and bisaccate pollen grains. In contrast, in the upper part, from Samples 603B-37-1, 34-36 cm to 603B-33-1, 80-82 cm, the organic residue is abundant and is dominated by well-preserved amorphous debris. Dinocysts and dinoflagellate species dominate the assemblages, with minor amounts of bisaccate pollen, angiosperm pollen, and the smaller pteridophyte spores in Gleicheniidites and Cyathidites. Classopollis is extremely rare, as it is represented by only a few specimens in the entire upper part of unit KX5.

12. Samples 603B-32-2, 71-73 cm, 603B-31-5, 5-7 cm, 603B-30-5, $3-5 \mathrm{~cm}$, and $603 \mathrm{~B}-29-2,45-47 \mathrm{~cm}$ are barren of palynomorphs in the micrinitic facies.

13. KT5 (CT): Samples 603B-29-1, 65-67 cm, 603B-28-4, 96-98 cm, and $603 \mathrm{~B}-26-4,27-29 \mathrm{~cm}$. The interval represented by these samples contain abundant carbonized tracheids and thus are close to the predominant facies in unit KT4 (CT).

The samples from 603B-25 to 603B-22 are barren of palynomorphs. All are characterized by the micrinitic facies, except for Sample 603B-22-4, 108-110 cm, which contains a sparse residue of the poorly preserved xenomorphic facies, as well as carbonized fecal pellets. 


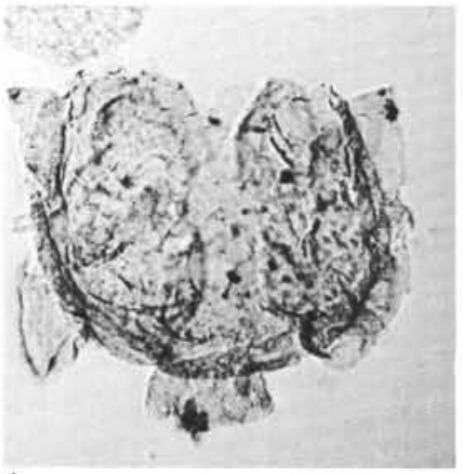

1
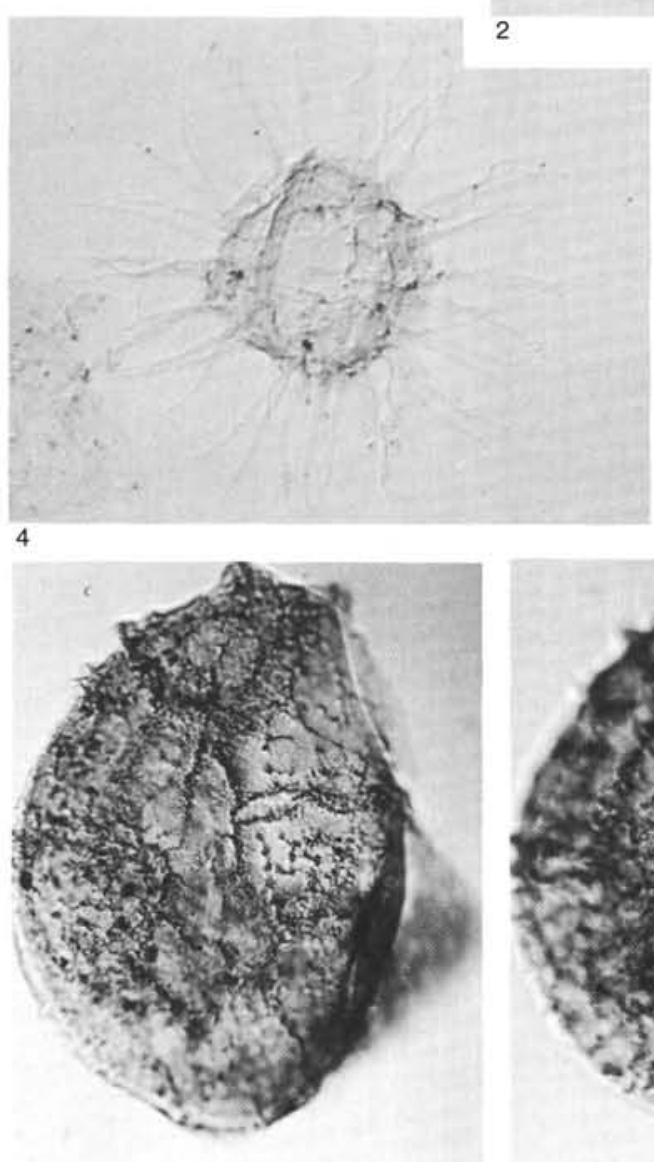

$7 \mathrm{~A}$
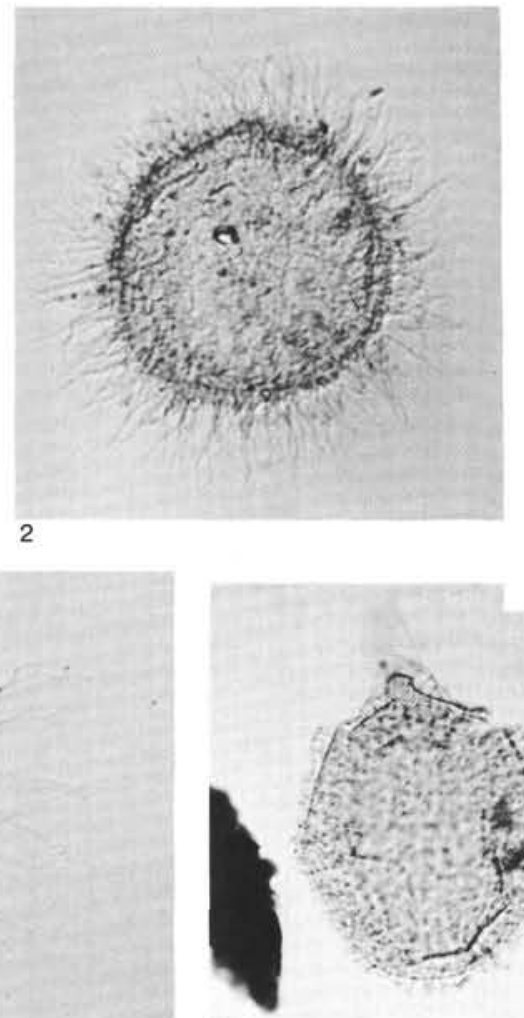

5

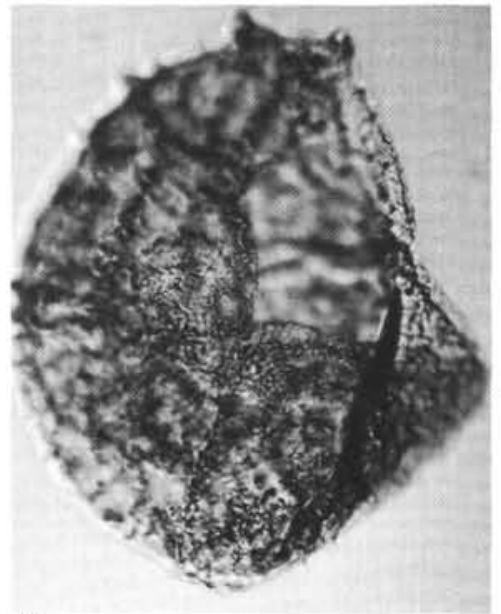

$7 \mathrm{~B}$

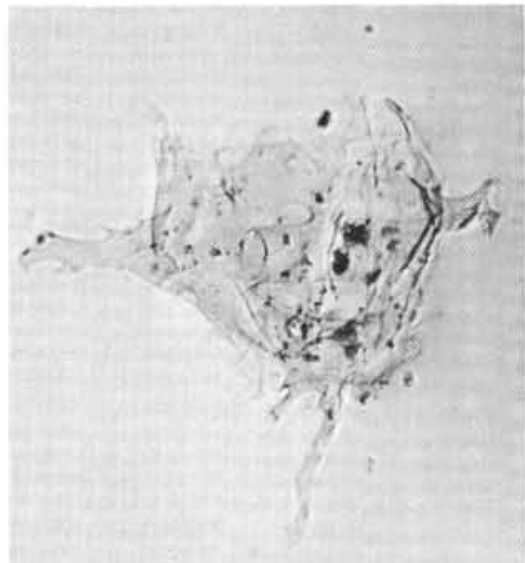

3

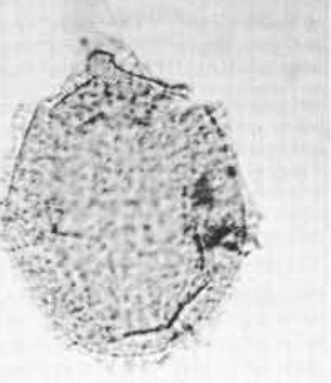

6
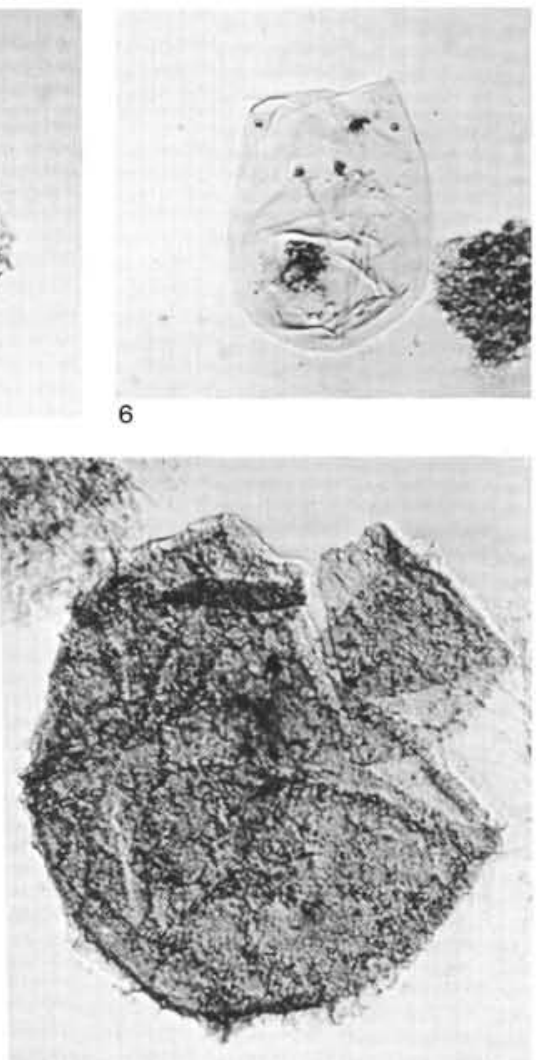

8

Plate 1. Dinoflagellate species in Hole 603B. (Magnifications not to scale; dimensions in $\mu \mathrm{m}$.) 1. Amphorula metaelliptica Dodekova, $67 \times 75$ $\mu \mathrm{m}$; Sample 603B-82-5, 51-53 cm. 2. Cometodinium whitei (Deflandre and Courteville), $87 \times 90 \mu \mathrm{m}$; Sample 603B-82-5, 51-53 cm. 3. Phoberocysta neocomica (Gocht), $93 \times 99 \mu \mathrm{m}$; Sample 603B-70-6, 8-10 cm. 4. Hystrichodinium pulchrum Deflandre, $90 \times 104 \mu \mathrm{m}$ (processes approximately $30 \mu \mathrm{m}$ long); Sample 603B-34-6, 15-17 cm. 5. Gardodinium eisenackii Alberti, $73 \times 49 \mu \mathrm{m}$; Sample 603B-47-1, 80-82 cm. 6. Prismatocystis cylindrica Habib, $55 \times 42 \mu \mathrm{m}$; Sample 603B-76-5, 19-21 cm. 7, 8. Diacanthum hollisteri Habib emended, Sample 603B-82-5, $51-53 \mathrm{~cm}$, (7) $105 \times 87 \mu \mathrm{m}$ (A, ventral (external) view of ventral surface; B, $2 \mathrm{P}_{2^{\prime \prime}}{ }^{-3}{ }^{\prime \prime}$ archeopyle evident; tabulation given in Fig. $5 \mathrm{~A}, \mathrm{~B}$ in the text); (8) $103 \times 93 \mu \mathrm{m}$, left lateral surface, showing $2 \mathrm{P}_{2{ }^{\prime \prime}-3{ }^{\prime \prime}}$ archeopyle and dislodged operculum consisting of a single piece. 

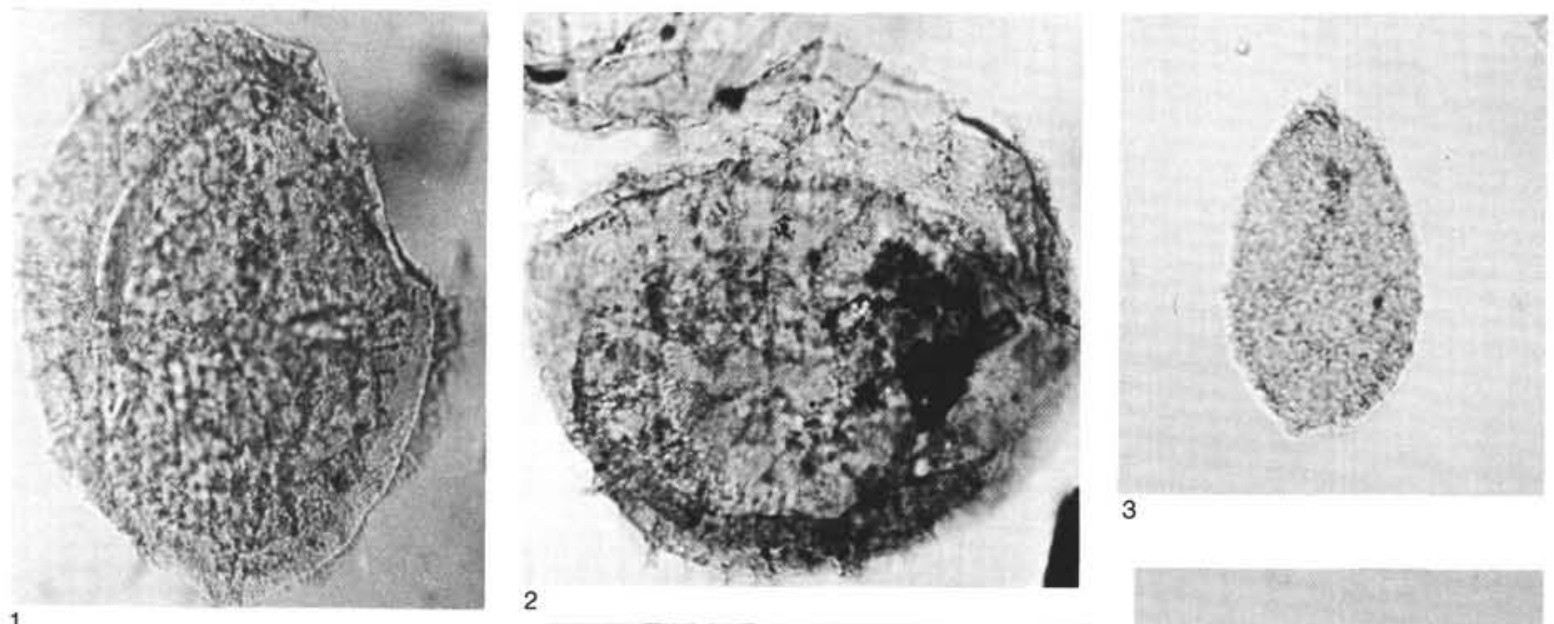

2

1
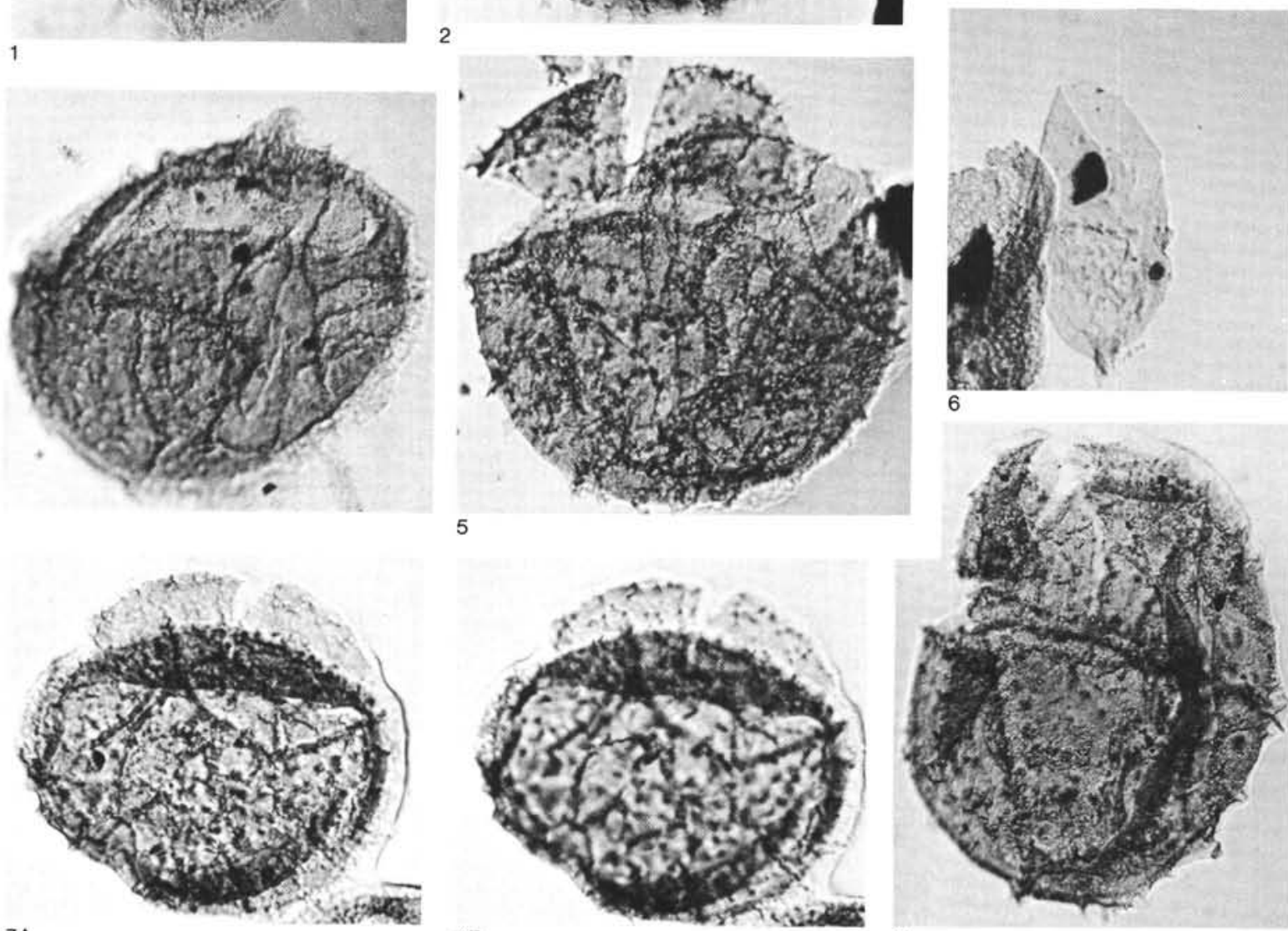

$7 \mathrm{~A}$

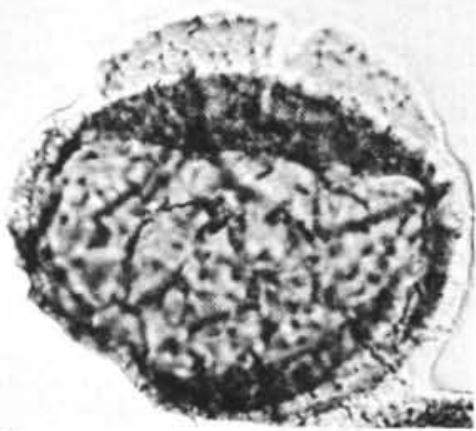

$7 B$

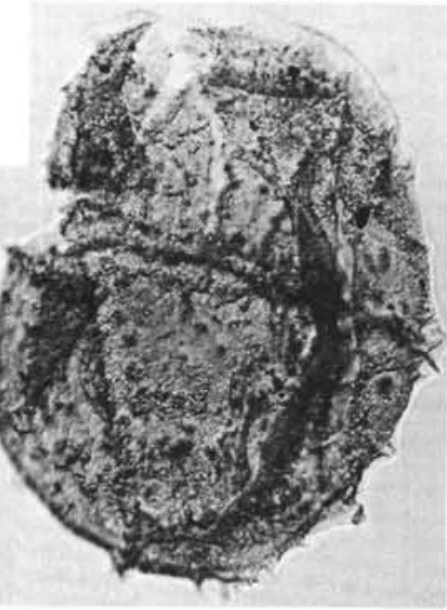

Plate 2. Dinoflagellate species in Hole 603B. (Magnifications not to scale; dimensions in $\mu \mathrm{m}$.) $1, \mathbf{2}, \mathbf{4 , 5}, \mathbf{7}, \mathbf{8}$. Diacanthum hollisteri, Sample 603B-82-5, 51-53 cm, (1) $105 \times 80 \mu \mathrm{m}$, left-lateral surface, showing $\mathrm{P}_{3^{\prime}}$, archeopyle in profile; (2) $97 \times 103 \mu \mathrm{m}$, dorsal (external) view of dorsal hypocyst, internal view of apical series, showing arrangement of apical plates and preapical plate. Apical series is reversed in schematic tabulation in Fig. $5 \mathrm{~F}$ in the text, in order to illustrate the apical view of the apical series; (4) $76 \times 82 \mu \mathrm{m}$, ventral (external) view of ventral surface. Note relatively long medial splitting of the sulcus. Ventral surface tabulation depicted in Fig. 5C in the text. Archeopyle in dorsal surface is evident; (5) $92 \times 84 \mu \mathrm{m}$, two opercular pieces are dislodged to produce archeopyle; (7) $64 \times 77 \mu \mathrm{m}$ apical-antapical compression (A, antapical (external) view of antapical surface, with single antapical plate indented by posterior sulcal plate at this ventral margin; B, internal view of apical surface; archeopyle $2 \mathrm{P}_{2}{ }^{\prime \prime}-3^{\prime \prime}$, with two opercular pieces attached at the cingulum); (8) lateral view, archeopyle $2 \mathrm{P}_{3^{\prime \prime}}-4^{\prime \prime}$, two opercular pieces. Opercular piece representing the third precingular plate is dislodged but remains close to the archeopyle, whereas that representing the smaller, quadrate fourth precingular plate remains attached at the cingulum. Schematic illustration of this specimen is given in Fig. 5D,E in the text. 3. Aprobolocysta varigranosa Duxbury, $68 \times 34 \mu \mathrm{m}$; Sample 603B-75-5, 50-52 cm. 6. Batioladinium micropodum Eisenack and Cookson), $69 \times 31 \mu \mathrm{m}$ Samples 603B-75-5, 50-52 cm. 

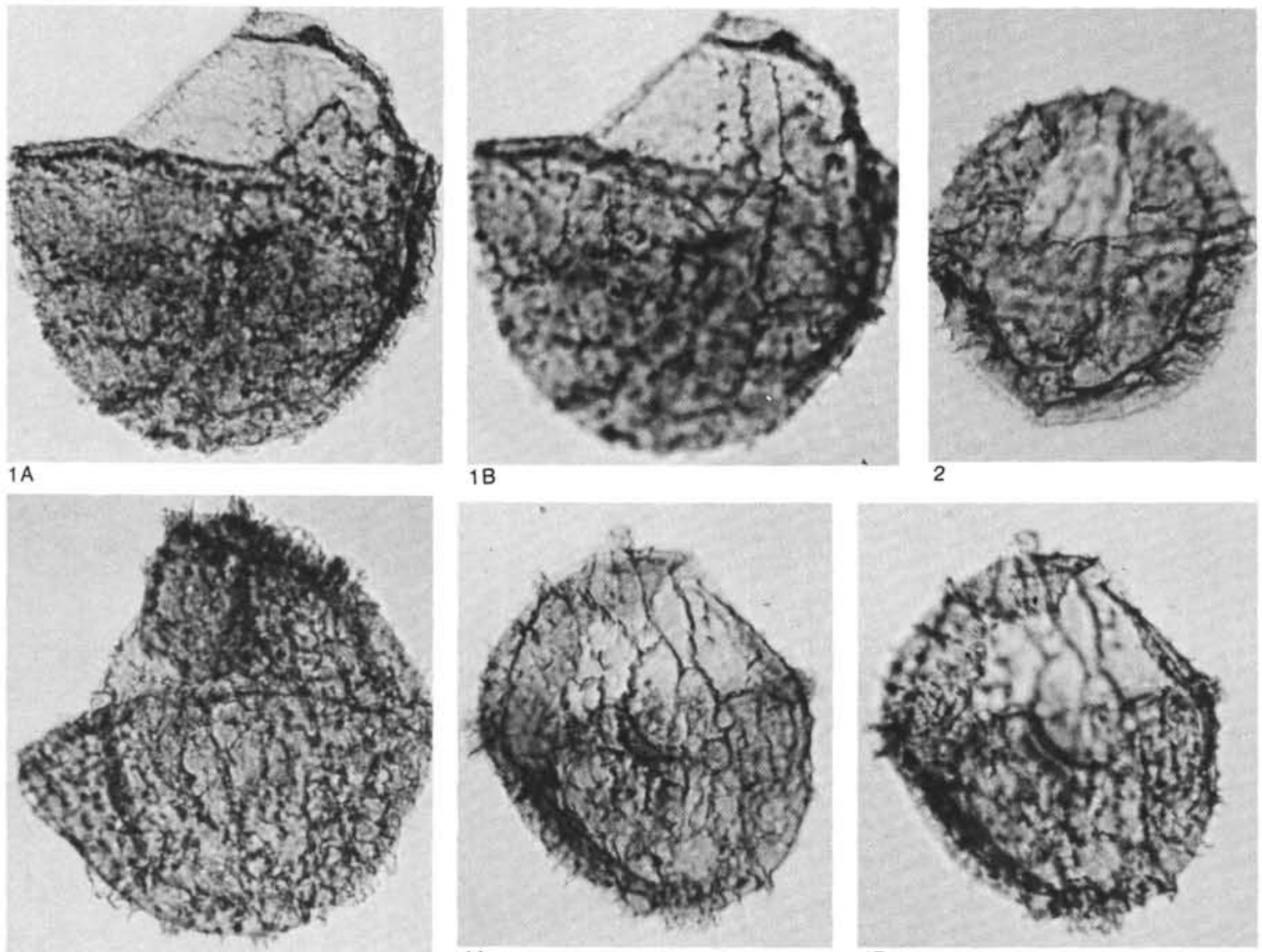

$1 \mathrm{~B}$

2
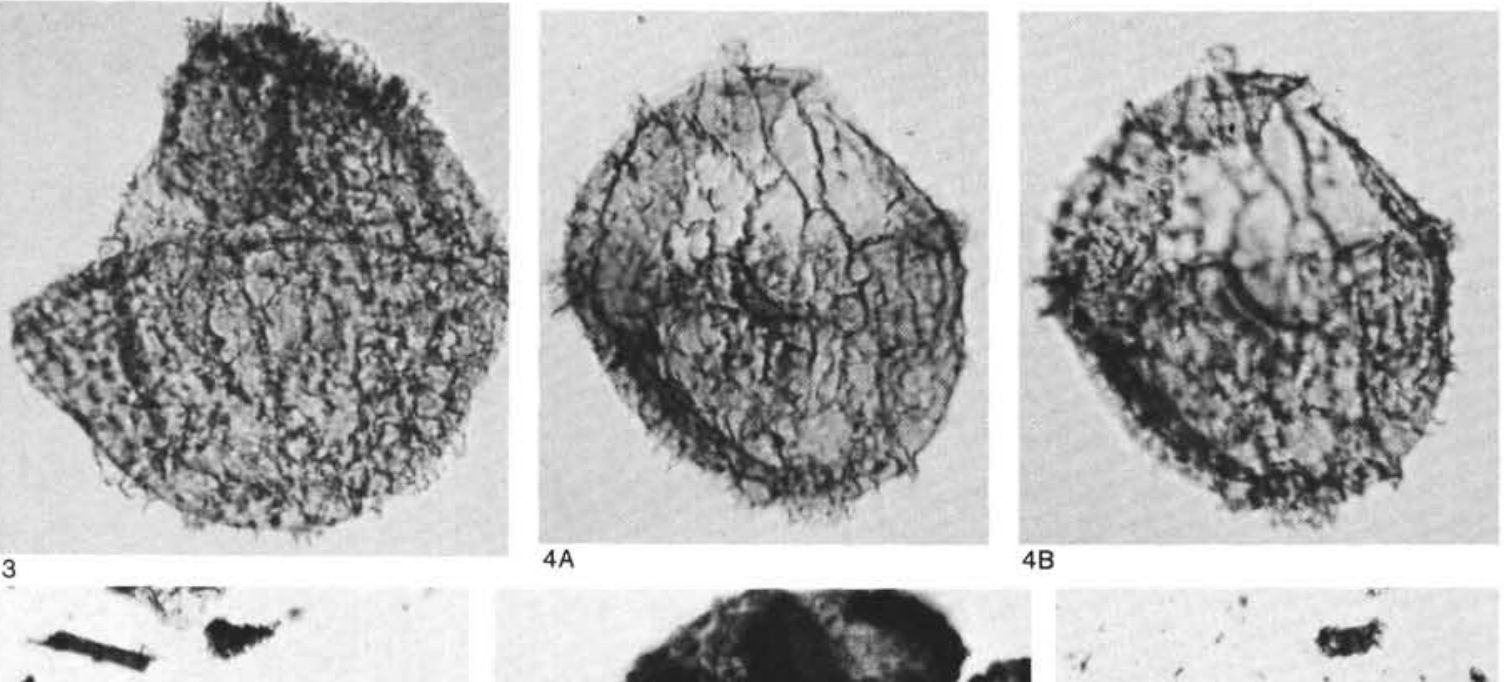

$4 \mathrm{~A}$

4B
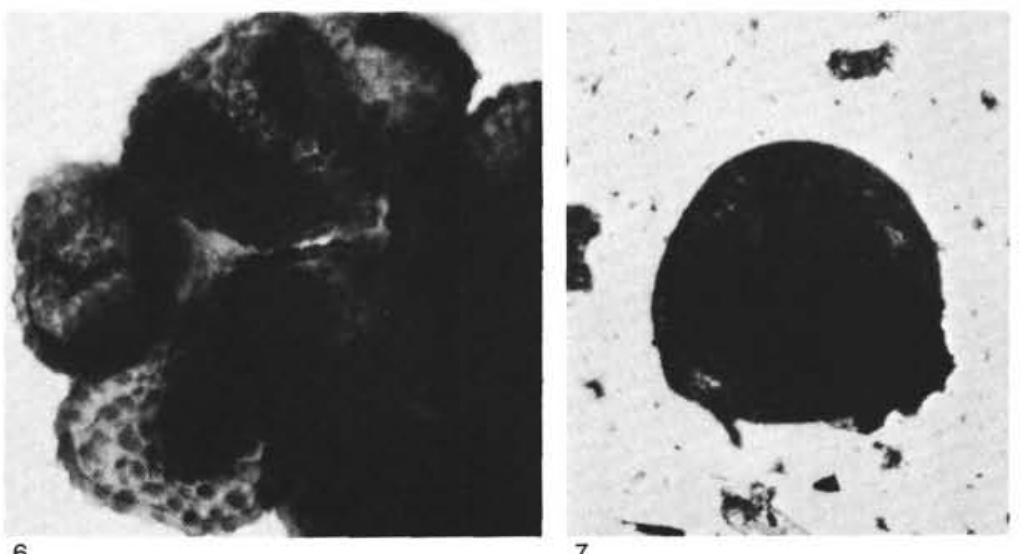

Plate 3. (Magnifications not to scale; dimensions in $\mu \mathrm{m}$.) 1-4. Diacanthum hollisteri, specimens from the stratotype region in France, (1) $98 \times 99$

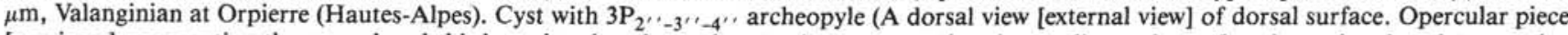
[or pieces] representing the second and third precingular plates absent; piece representing the small, quadrate, fourth precingular plate remains attached at the cingulum. Note the internal view of the high, slender, attenuated first precingular plate on the ventral surface; B, dorsal view [internal view] of ventral surface. Focus on reversed relationship of first and fourth apical plates, anterior sulcal plate, and sixth precingular plate); (2) $77 \times 75 \mu \mathrm{m}$, Berriasian at Ginestous-la Garenne (Héraoult). Cyst with $\mathrm{P}_{3}$, archeopyle formed by loss of a single, mid-dorsal, third precingular plate; (3) $100 \times 99 \mu \mathrm{m}$, Valanginian at LaCharce (Drôme). Right lateral view (external view) of right lateral surface. Cyst with fourth precingular plate dislodged but remaining almost in place; (4) $89 \times 77 \mu \mathrm{m}$, Valanginian at Orpierre (Hautes Alpes), Thurmanniceras pertransiens ammonite Zone (A, ventral view [external view] of ventral surface. Focus of sulcus and adjacent cyst tabulation; medial splitting of the sulcus is evident, extending from within the posterior sulcal plate to adjacent the first postcingular plate. The high and slender first precingular plate, the relatively wide fifth precingular plate, and the narrow sixth precingular plate are evident; B, ventral view [internal view] of dorsal surface. 3P archeopyle is in focus. Opercular piece representing the second precingular plate remains attached at the cingulum; operculum otherwise absent. Note characteristic outlines of high pentagonal third precingular plate, small quadrate fourth precingular plate, and protruding lips of both second and third apical plates into archeopyle). 5-7. Terrigenous organic detritus in the exinitic facies at Site 603, Sample 603B-56-3, 81-83 cm; $(5,6)$. Sporangial mass of spores in Converrucosisporites sp., $5, \sim 550 \mu \mathrm{m}$ long; $\sim 40$ to 50 spores occur; 6 , Enlarged view of spores (in polar view approximately $71 \mu \mathrm{m}$ in diameter); (7). Unidentified magaspore, $\sim 400 \mu \mathrm{m}$ in diameter. 


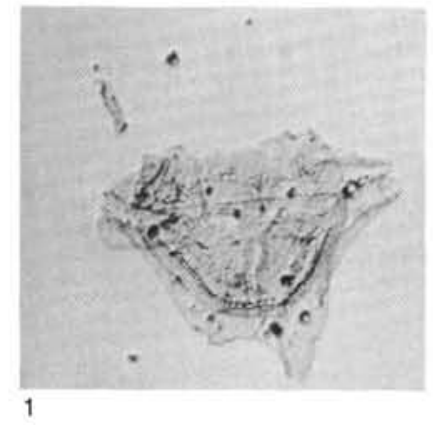

1

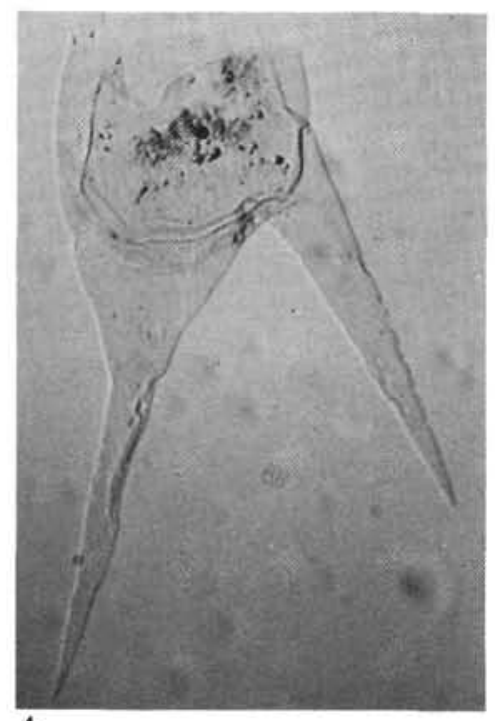

4

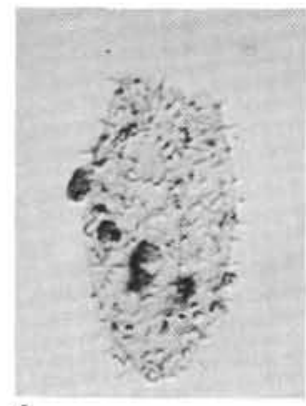

8

9

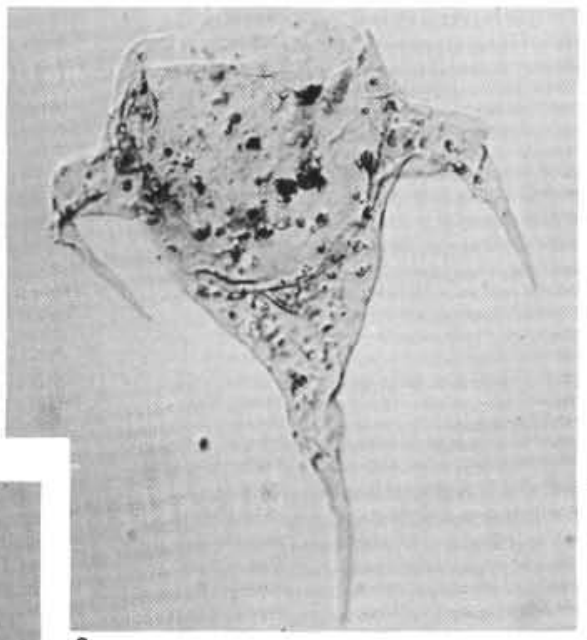

2
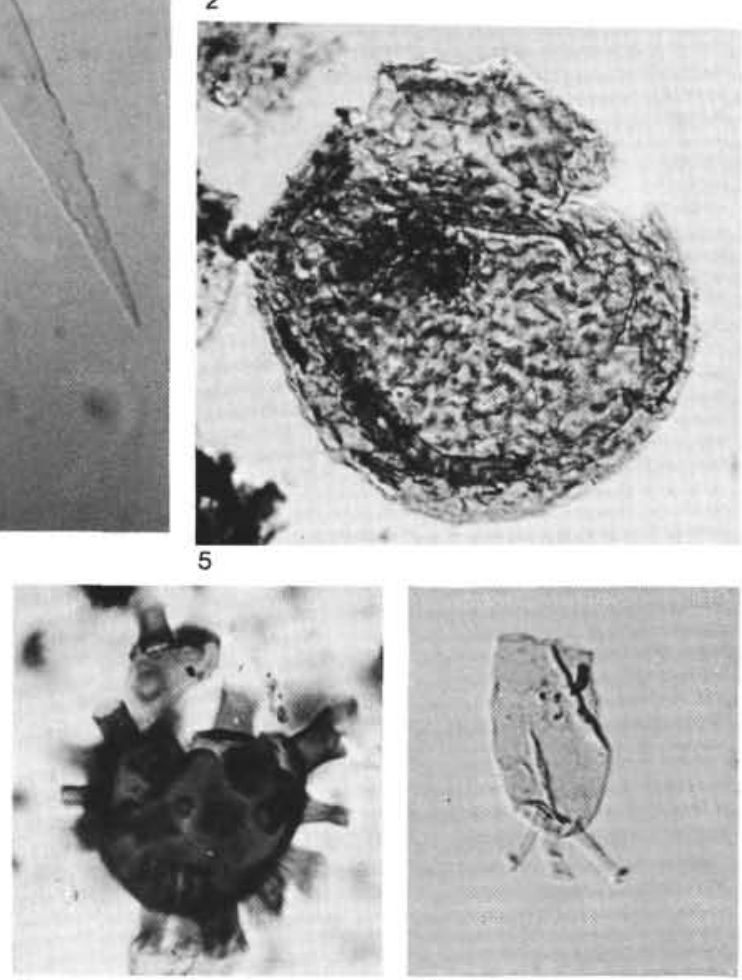

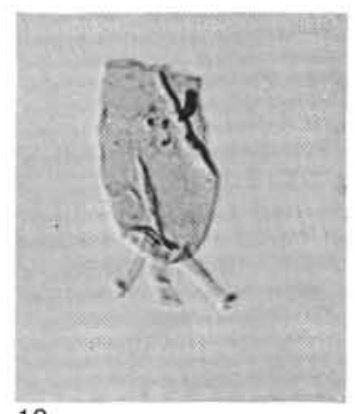

10

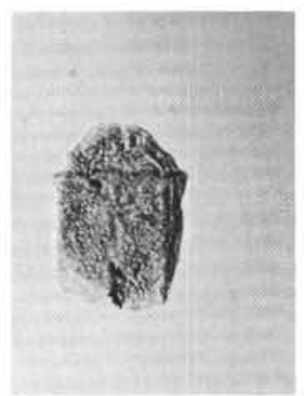

3

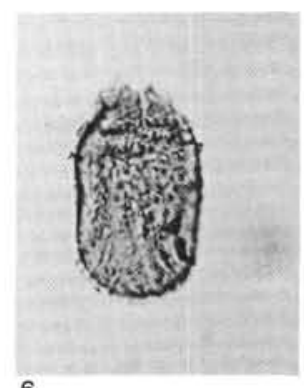

6

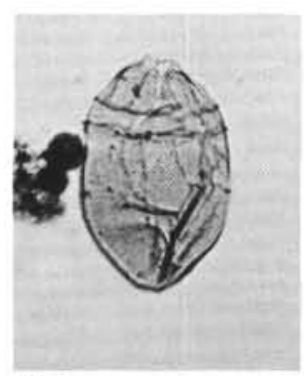

7

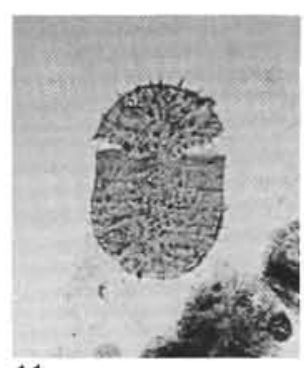

11

Plate 4. Dinoflagellate species in Hole 603B. (Magnifications not to scale; dimensions in $\mu \mathrm{m}$.) 1. Muderongia simplex Alberti, $52 \times 62 \mu \mathrm{m}$, Sample 603B-69-7, 22-24 cm. 2. Muderongia tetracantha (Gocht), $130 \times 94 \mu \mathrm{m}$, Sample 603B-55-5, $12-14 \mathrm{~cm}$. 3. Druggidium rhabdoreticulatum Habib, $36 \times 26 \mu \mathrm{m}$, Sample 603B-60-4, 16-18 cm. 4. Odontochitina operculata (Wetzel), $135 \times 94 \mu \mathrm{m}$, Sample 603B-34-1, 70-72 cm. 5. Cassiculosphaeridia magna Davey, $94 \times 91 \mu \mathrm{m}$, Sample 603B-75-5, 50-52 cm. 6. Druggidium deflandrei (Millioud), $41 \times 26 \mu \mathrm{m}$, Sample 603B-50-1, 58-60 cm. 7. Druggidium apicopaucicum Habib, $44 \times 29 \mu \mathrm{m}$, Sample 603B-58-6, 65-67 cm. 8. Prolixosphaeridium parvispinum (Cookson and Eisenack), $62 \times 31 \mu \mathrm{m}$, Sample 603B-49-1, 120-122 cm. 9. Lithosphaeridium arundum (Eisenack and Cookson), $43 \times 47 \mu \mathrm{m}$ (operculum not measured), Sample 603B-39-5, 57-59 cm. 10. Bourkidinium sp., $52 \times 23 \mu \mathrm{m}$, Sample 603B-58-6, 65-67 cm. 11. Biorbifera johnewingii Habib, $36 \times 26 \mu \mathrm{m}$, Sample 603B-77-7, 13-15 cm 

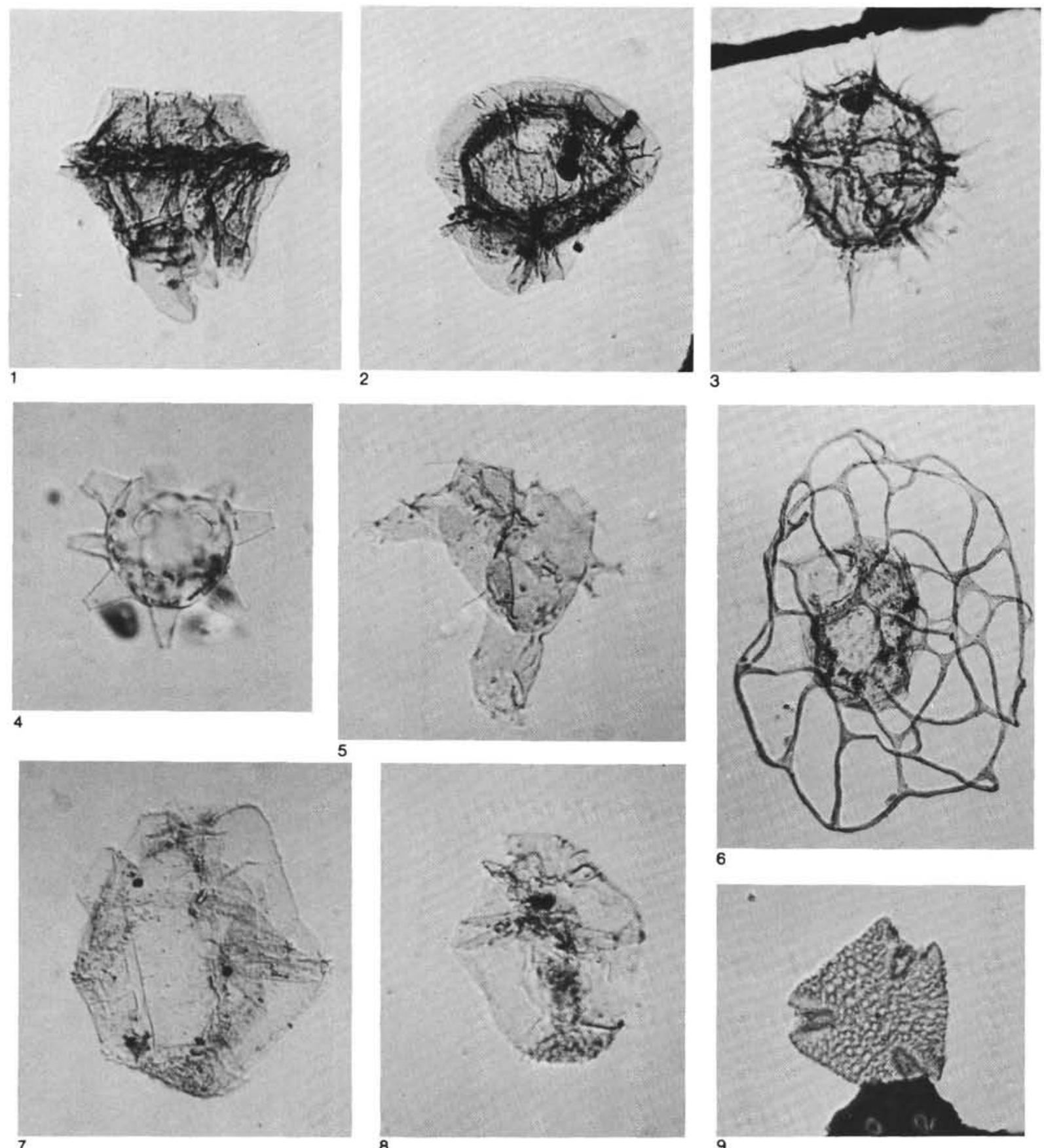

6

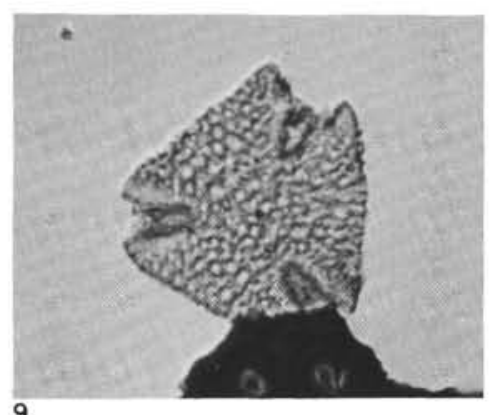

Plate 5. Dinoflagellate and pollen species in Hole 603B. (Magnifications not to scale; dimensions in $\mu \mathrm{m}$.) 1, 2. Dinopterygium cladoides Deflandre, Sample 603B-39-5, 57-59 cm, (1) 65-62 $\mu \mathrm{m}$, apical archeopyle evident, with accessory sutures incompletely developed in the precingular series; (2) $60 \times 65 \mu \mathrm{m}$. 3. Xiphophoridium alatum (Cookson and Eisenack), $78 \times 70 \mu \mathrm{m}$, Sample 603B-39-5, 57-59 cm. 4. Litosphaeridium siphoniphorum glabrum Lucas-Clarke, $47 \times 57 \mu \mathrm{m}$, Sample 603B-34-6, 15-17 cm. $\quad$. Xenascus ceratioides (Defandre), $68 \times 73 \mu \mathrm{m}$, Sample 603B-39-5, 57-59 cm. 6. Hapsocysta peridictya (Eisenack and Cookson), $104 \times 78 \mu \mathrm{m}$, Sample 603B-42-6, 37-39 cm. 7, 8. "?Maduradinium" of Davey (1978), Sample 603B-34-6, 15-17 cm, (7) $80 \times 70 \mu \mathrm{m}$; (8) $65 \times 55 \mu \mathrm{m}$. 9. "Retitricolpites M" of Wolfe (1976), $44 \times 44 \mu \mathrm{m}$, Sample 603B-26-4, 27-29 cm. 

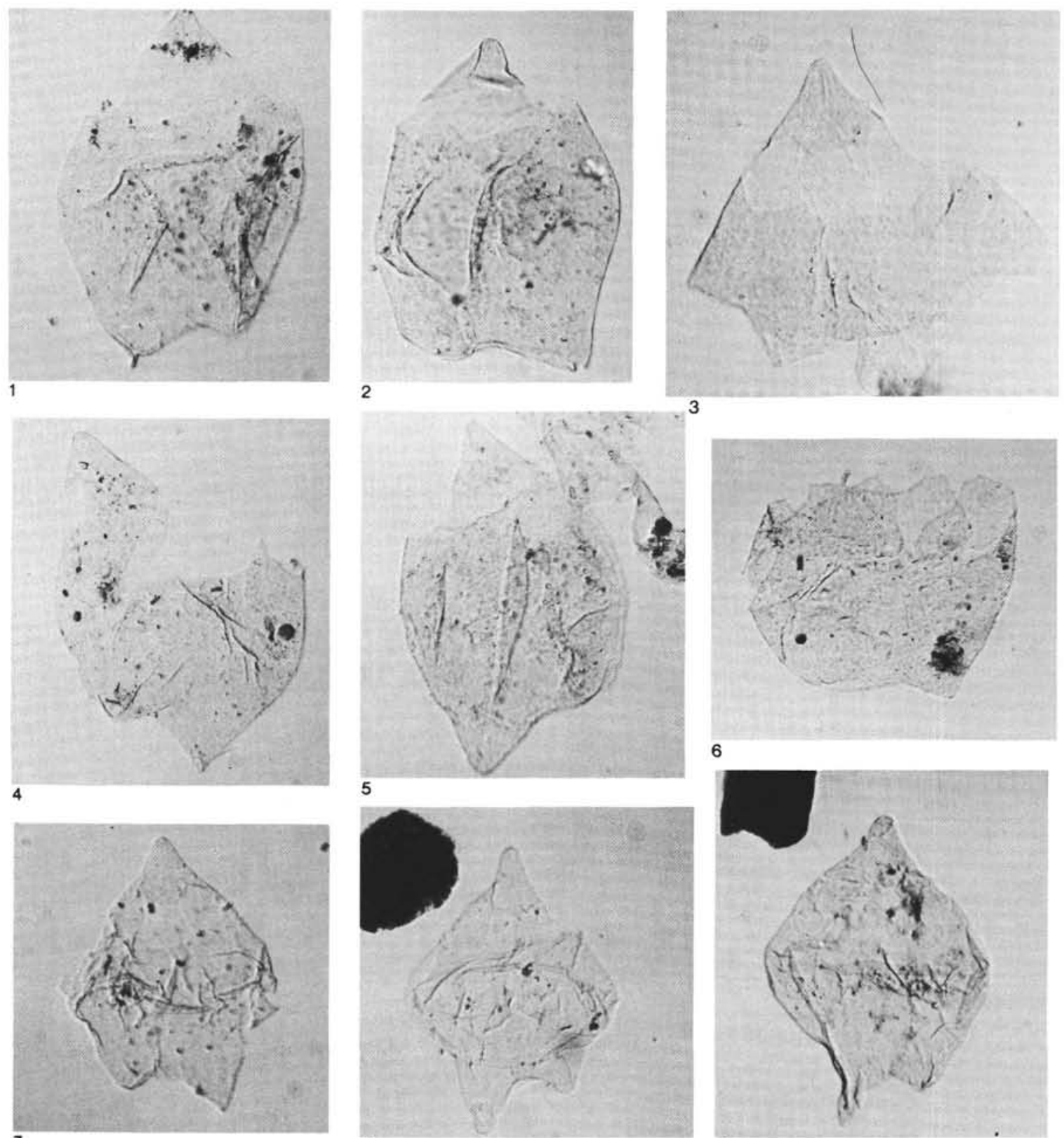

6

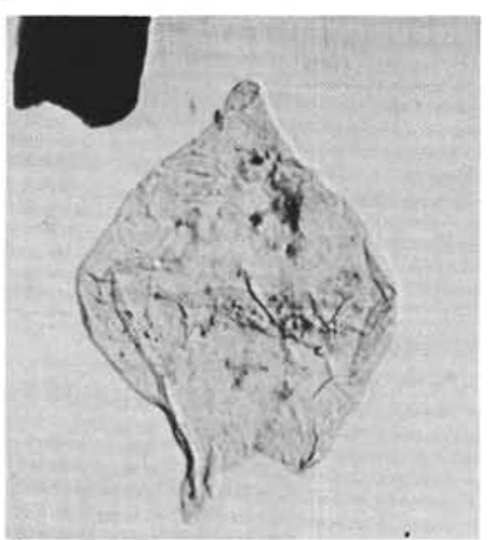

8

9

Plate 6. Dinoflagellate species in Hole 603B and Hole 605. (Magnifications not to scale; dimensions in $\mu \mathrm{m}$.) 1-6. Pierceites schizocystis n. gen., n. sp., Sample 603B-34-6, 15-17 cm, (1) holotype, $85 \times 61 \mu \mathrm{m}$; (2) $79 \times 58 \mu \mathrm{m}$; (3) $67 \mu \mathrm{m}$ wide, dehisced epicyst, showing sutural boundaries delimiting plates of apical, anterior intercalary (as archeopyle sutures) and precingular series; first apical plate does not reach apex; (4) $86 \times 60$ $\mu \mathrm{m}$, incompletely dihesced part of epicyst; precingular plates remain attached or close to the cyst near the ventral margin; intercalary archeopyle evident in profile at dorsal margin; (5) $85 \times 54 \mu \mathrm{m}$; (6) $65 \mu \mathrm{m}$ wide, hypocyst intact with epicystal precingular plates detached buy remaining close to the hypocyst; remaining epicystal series of plates absent. 7-9. Pierceites pentagonum (May) n. comb., Sample 605-70-6, 90-92 cm at Site 605 , (7) $73 \times 52 \mu \mathrm{m}$; (8) $75 \times 57 \mu \mathrm{m}$; (9) $81 \times 60 \mu \mathrm{m}$. 

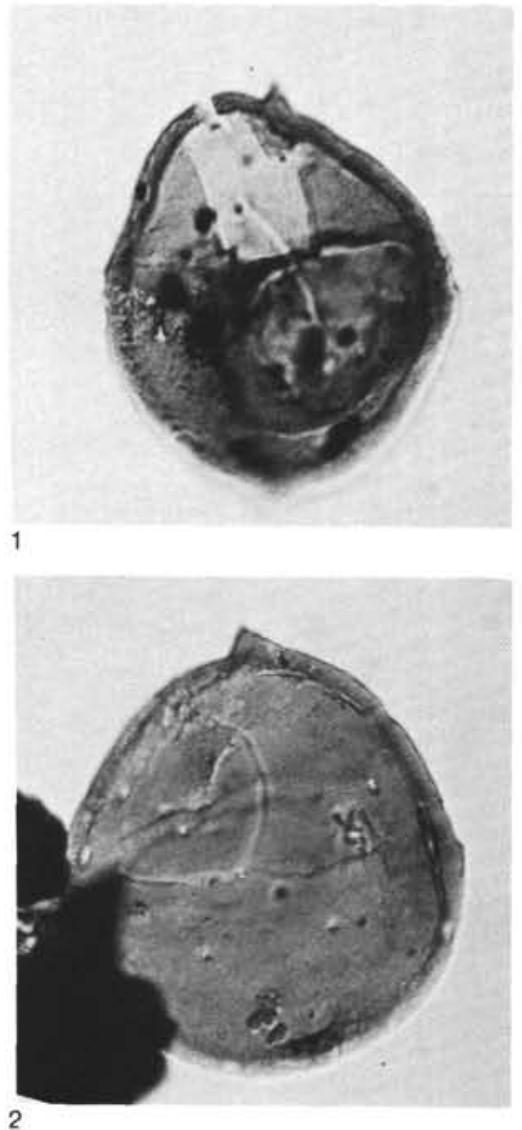

2

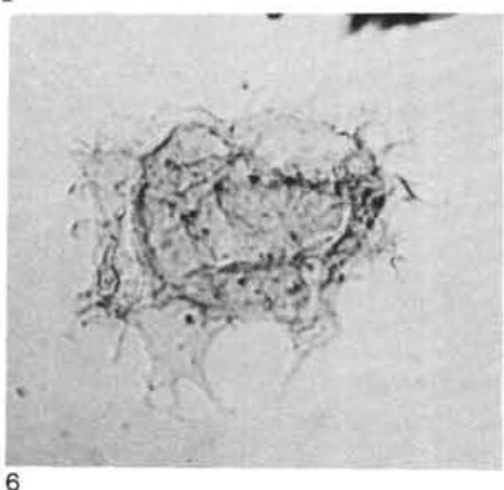

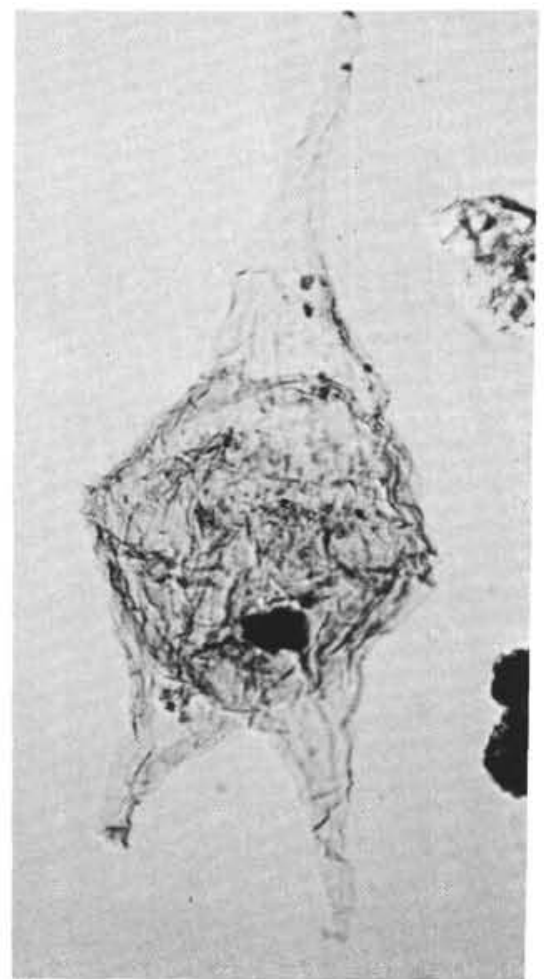

3

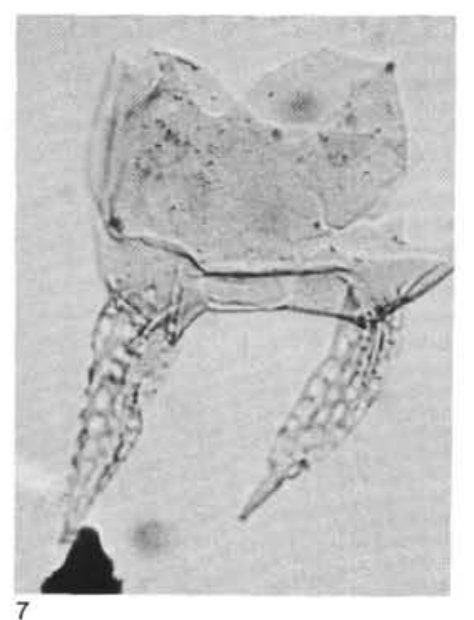

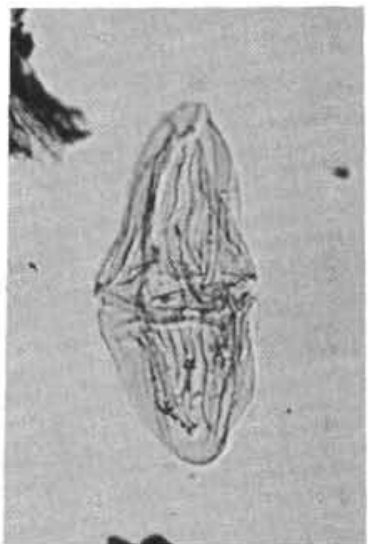

4

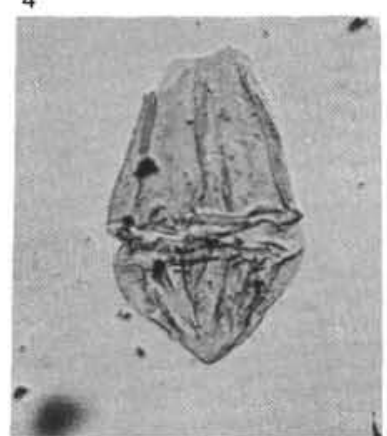

5

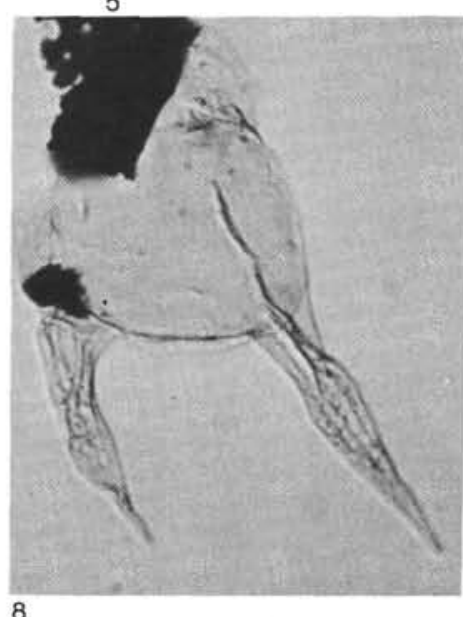

Plate 7. Dinoflagellate species in Hole 603B and Hole 605. (Magnifications not to scale; deminsions in $\mu \mathrm{m}$.) 1, 2. Carpatella cornuta Grigorovich, Sample 605-66-1, 61-64 cm, (1) $89 \times 70 \mu \mathrm{m}$; (2) $91 \times 82 \mu \mathrm{m}$, operculum free, but remains in place. 3. Deflandrea diebellii Alberti, Sample 605-70-6, 90-92 cm, $190 \times 73 \mu \mathrm{m}$. 4. Dinogymnium acuminatum Evitt, Clarke, and Verdier, Sample 603B-28-4, 96-98 cm, 75 $\times 31$ $\mu \mathrm{m}$. 5. Dinogymnium sp., Sample 603B-26-4, 27-29 cm, $65 \times 39 \mu \mathrm{m}$; evidence of an apical archeopyle, with ventral side to the left and dorsal side to the right. 6. Palynodinium grallator Gocht, Sample 605-66-1, 78-81 cm, $65 \times 70 \mu \mathrm{m}$. 7, 8. Odontochitina porifera Cookson, (7) Sample 603B-28-4, 96-98 cm, $104 \times 75 \mu \mathrm{m}$;(8) Sample 603B-26-4, 27-29 cm, $104 \times 60 \mu \mathrm{m}$. 

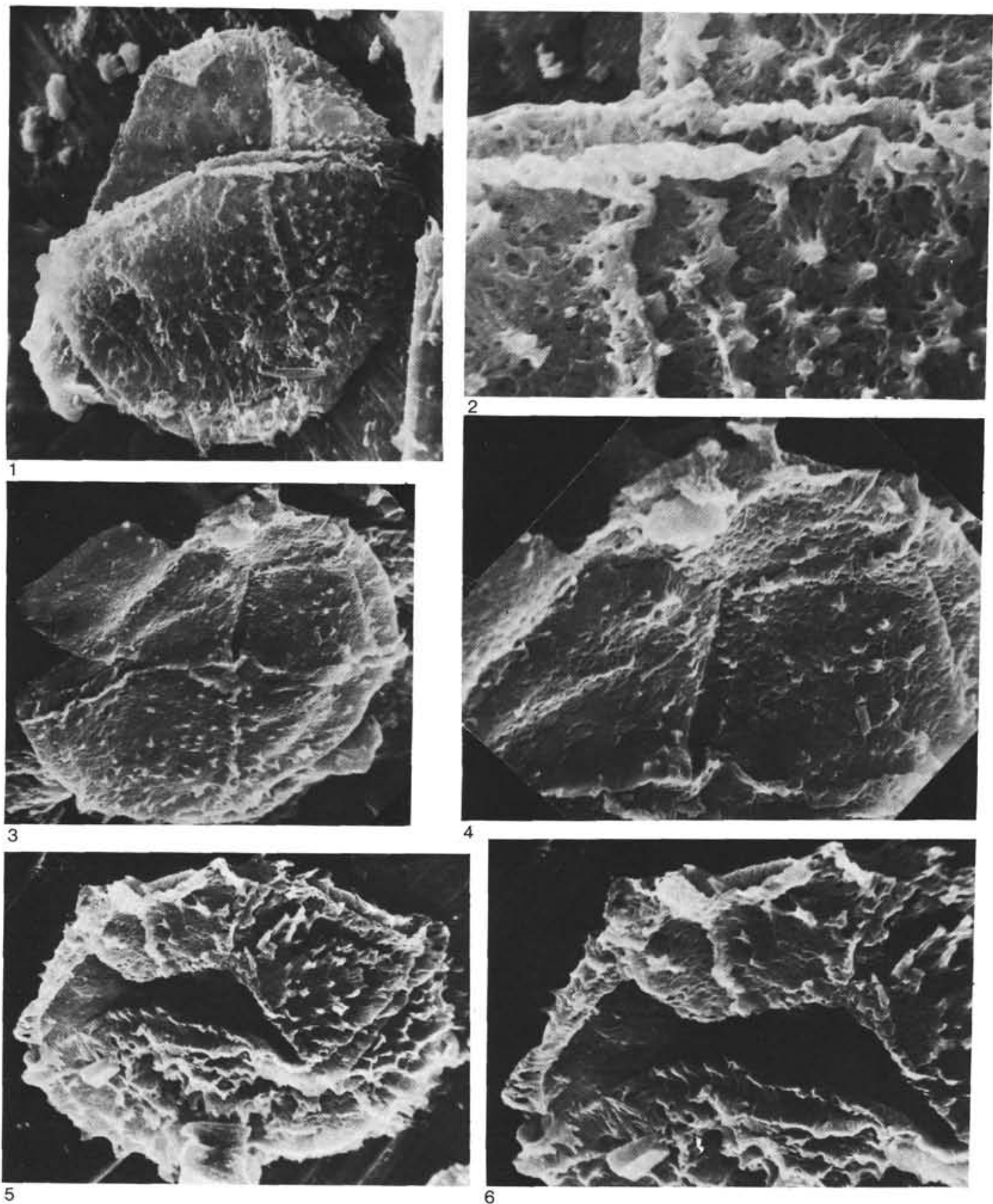

Plate 8. Scanning electron micrographs of Diacanthum hollisteri in Sample 603B-82-5, 51-53 cm. 1. $\times 700,90 \times 85 \mu \mathrm{m}$; dorsal surface showing $2 \mathrm{P}_{2^{\prime \prime}-3^{\prime \prime}}$ archeopyle and relatively small, nearly rectangular fourth postcingular plate. $2 . \times 1650$, enlarge view of specimen illustrated in Fig. 1 ; surface characterized by pseudoreticulate mosaic of intratabular spines and perforations. Spinate intratabular ridge lies within the fifth postcingular plate adjacent the $4^{\prime \prime \prime} / 5^{\prime \prime \prime}$ ' septal plate boundary. Cyst tabulation of narrow cingulum not discerned. 3 . $\times 700,75 \times 87 \mu$ m; right lateral surface. Cyst with opercular piece, representing the second and third precingular plates, partially detached. Incipient detachment of fourth precingular plate along $3^{\prime} / 4^{\prime}$ ' boundary. Note configuration of almost rectangular second precingular plate, pentagonal third precingular plate, and smaller, quadrate, fourth precingular plate. 4. $\times 1200$, enlarged view of specimen illustrated in Fig. 3. Boundary between opercular pieces of precingular series and the apical series is sutural and not septal. Septal boundary evident between fifth precingular plate and apical series. Pentagonal preapical plate present at top of apical horn; it is divided by a raised partition. 5 . $\times 750,80 \times 90 \mu$ m; archeopyle $2 \mathrm{P}_{2}^{\prime \prime \prime}-3^{\prime \prime}$. Curving, intratabular spinate ridge, and cluster of intratabular spines, evident in fourth precingular plate. $6 . \times 1300$. Second apical plate forms lip protruding into archeopyle. Third apical plate does not reach apical horn. Evidence of anterior intercalary plates absent. 

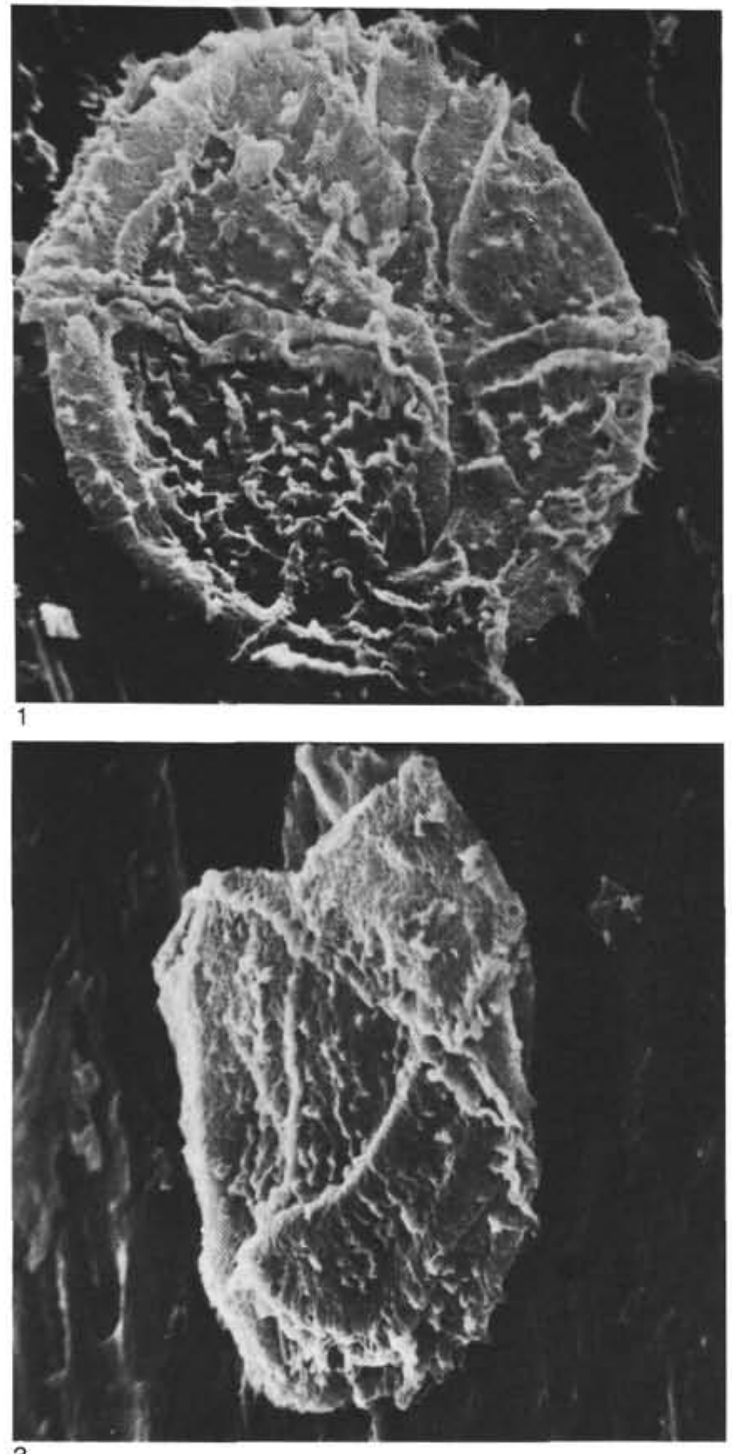

3

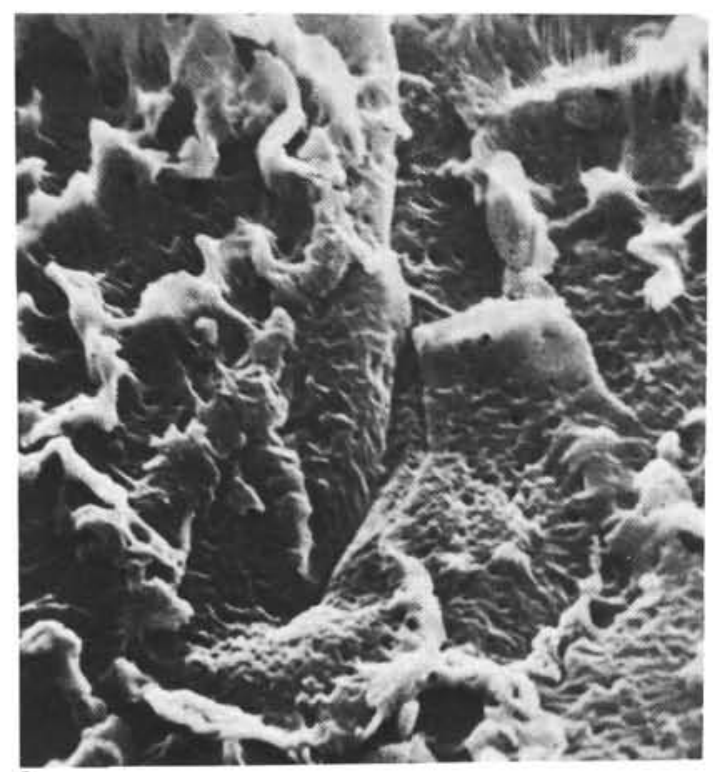

2

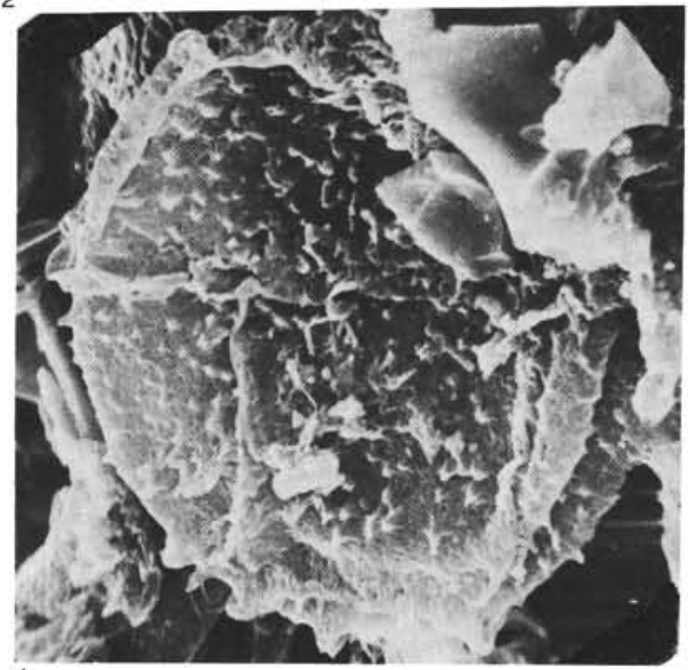

4

Plate 9. Scanning electron micrographs of Diacanthum hollisteri in Sample 603B-82-5, 51-53 cm. $\quad 1 . \quad \times 800,85 \times 85 \mu \mathrm{m}$, cyst tabulation of ventral surface. Margin near left side of photograph is folded. 2. $\times 2000$, medial splitting of the sulcus extends from within posterior sulcal plate to the intersection of the cingulum and the sulcus. 3. $\times 800,88 \times 50 \mu \mathrm{m}$, right lateral surface. Archeopyle $3 \mathrm{P}$, with quadrate fourth precingular and the plate attached at the cingulum. Hypocystal fifth postcingular plate is folded. $4 . \times 800,85 \times 85 \mu$ m, dorsal surface. Relatively small, rectangular fourth postcingular plate is evident. Operculum is free, but remains in place; it is represented by a single opercular piece. Large fold is situated at margin near right side of illustration. 